\title{
THE MULTICRITERIA ASSESSMENT METHODOLOGY OF THE DECISION SUPPORT SYSTEM IMPLEMENTATION EFFECTIVENESS
}

\author{
Lilianna WAŻNA* \\ Tadeusz KRUPA** \\ * Faculty of Economics and Management \\ University of Zielona Góra, 65-417 Zielona Góra, Poland \\ email: 1.wazna@wez.uz.zgora.pl \\ **Faculty of Management \\ Warsaw University of Technology, 02-524 Warszawa, Poland \\ email: t.krupa@wz.pw.edu.pl
}

\begin{abstract}
The multi-criteria assessment methodology of implementation effectiveness of information systems illustrated by an example of decision support system (DSS) realized in w information technologies is presented in the article. The assessment of DSS under consideration takes place using the knowledge recorded in the form of fuzzy neural network, collected in an enterprise, on the basis of earlier realized implementations of other information systems. A model of retrieved DSS is expressed by means of a set of functionalities serving business processes of the enterprise under consideration. A model of implementation undertaking determined by means of a set of preparatory actions for the implementation and a set of directly implementation and exploitation actions is built for the retrieved DSS as well. Furthermore, a vector determining a current and planned implementation state of a set of DSS functionalities in the enterprise at time moments, before and after the commencement of planned implementation of the retrieved DSS is built. A concept of trapezoidal fuzzy numbers is used in building DSS models. An adjustment of fuzzy parameters of DSS models takes place by means of geometrical method of maximum absolute error points. A presented methodology enables to execute a multi-criteria effectiveness assessment of planned undertaking in relation to subjective criteria established by the enterprise (preferred time, cost and values of priority indexes). Additionally, the knowledge collected on the basis of earlier realized implementations of information systems and applied imprecise description of parameters taking into account errors made in their estimation in the past is used.
\end{abstract}

Keywords: decision support system, empirical knowledge base, prognostic decision, multi-criteria assessment methodology implementation effectiveness, decision making space model, uncertainty conditions, trapezoidal fuzzy numbers, fuzzy neural network, fuzzy reasoning.

\section{$1 \quad$ Introduction}

The multi-criteria assessment methodology of decision support system implementation effectiveness (MAM DSS IME) is adapted to making prognostic decisions concerning an assessment of effectiveness indexes which can be achieved by an enterprise in a process of DSS implementation in uncertainty conditions. The assessment takes place using the knowledge collected in the enterprise on the basis of earlier realized implementations of other information systems and recorded in the form of fuzzy neural network.

\section{The essence of decision making space model}

A structure of decision making space model used for the needs of the multi-criteria assessment methodology of decision support system implementation effectiveness (MAM DSS IME) combines:

- DSS business functionalities,

- actions, costs and time of implementations,

- experience expressed by indexes of effects gained by the under consideration when implementing other systems,

- established budget for the implementation,

- time limit of achievement of preferred implementation effects determined by the enterprise.

A concept of trapezoidal fuzzy numbers is used in building the model. The fuzzy numbers give a possibility to represent a part of parameters determined imprecisely what allows to express and analyse uncertainty included in a description of elements of the whole implementation. A trapezoidal fuzzy number in the form 
of $T_{i}=\left[T_{i \min }, T_{i \text { mL }}, T_{i m p}, T_{i \max }\right]$ describing a realization time limit is presented in Figure 1 as a description example of one of imprecisely determined parameters.

A scheme of decision making space model of DSS implementation effectiveness assessment is presented in Figure 2.
A DSS with functionalities (modules) $\mathrm{F}=\left\{\mathrm{F}_{1}, \ldots \mathrm{F}_{\mathrm{h}}\right\}$ serving business processes in the enterprise is given in the model, for example: $F=\{$ Basic data, Sales and distribution, Purchases, Materials management, Production, Accountancy\}.

The shortest possible

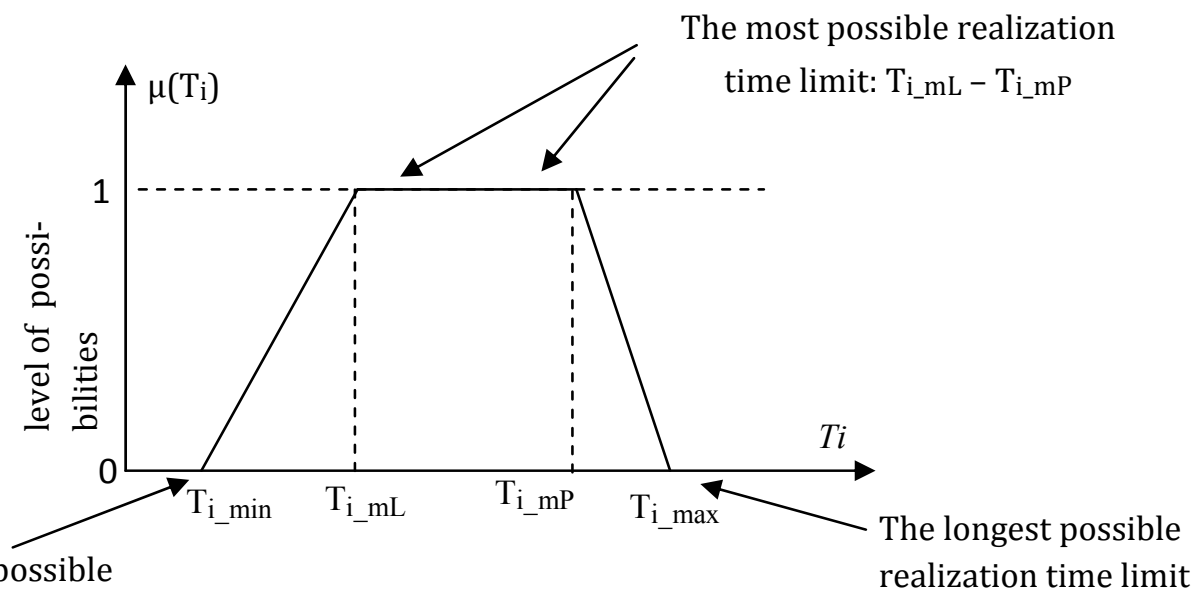
realization time limit

Figure 1. Realization time limit determined imprecisely by means of trapezoidal fuzzy number (source: self study)

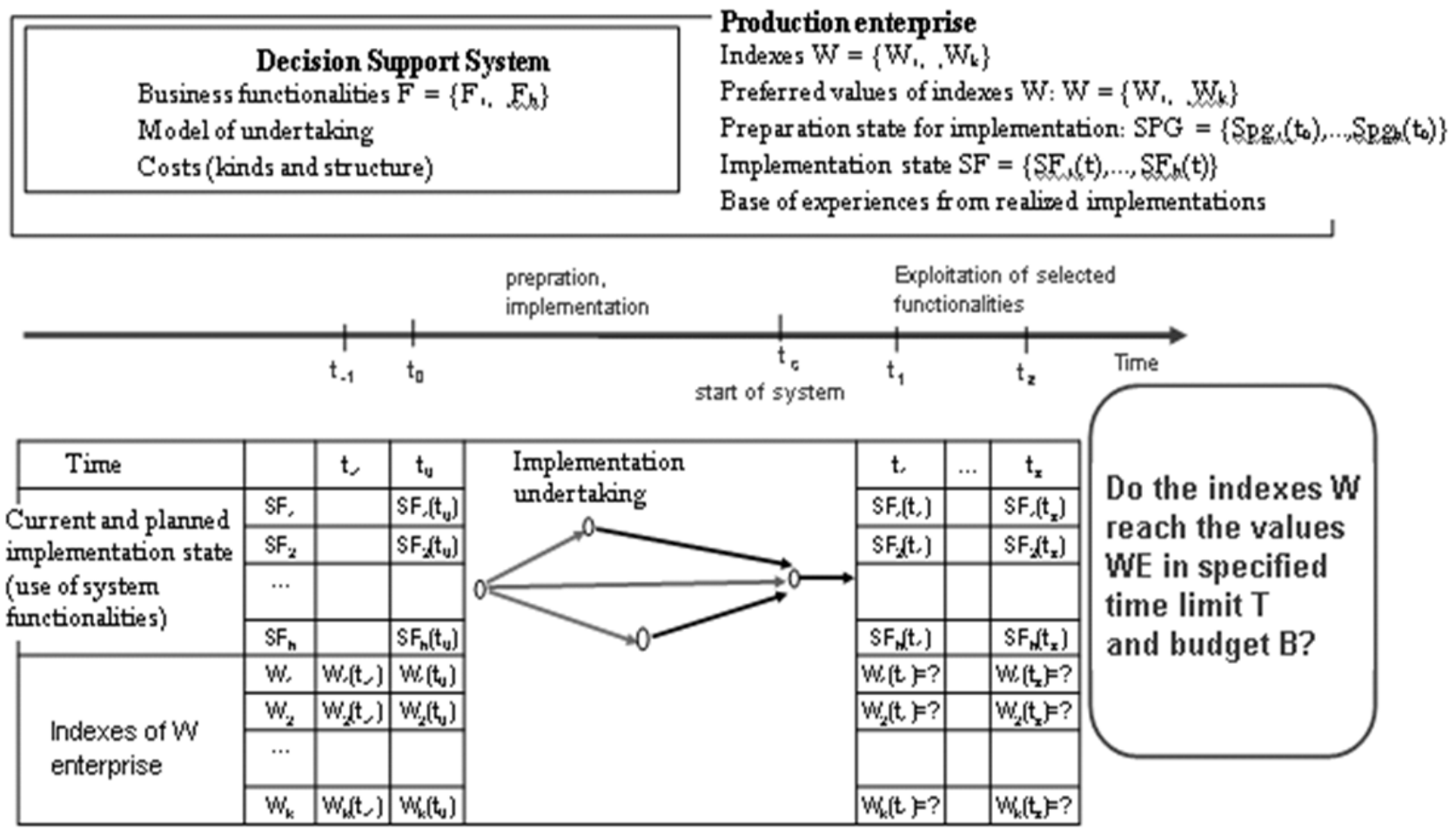

Figure 2. Decision making space model of DSS implementation effectiveness assessment (source: self study) 
The information on the costs connected with the system implementation are given for a specified DSS; the costs include:

- cost of system licence KLC corresponding with a determined number of users,

- vector of types of costs of RK connected with a planned implementation,

- vector of fixed costs KST, determining the rates of fixed costs accordingly to every type of costs,
- vector of reference rates ODN, determining the rates of reference for every type of costs, constituting a base of estimation of variable costs,

- vector of values of reference rates WOD, determining the value of individual reference rates,

- vector of unit variable costs KZM, determining the rates of unit variable costs for every reference rate.

The exemplary information on a DSS implementation costs is presented in Table 1 .

Table 1. Costs of DSS implementation undertaking - example

\begin{tabular}{|c|l|l|l|l|l|}
\hline \multicolumn{2}{|c|}{} & \multicolumn{1}{|c|}{$\begin{array}{c}\text { Fixed costs } \\
(\% \text { of licence costs }) \\
\text { KST }\end{array}$} & $\begin{array}{c}\text { Unit variable cost } \\
(\% \text { of fixed costs }) \\
\text { KZM }\end{array}$ & $\begin{array}{c}\text { Reference rate } \\
\text { ODN }\end{array}$ & $\begin{array}{c}\text { Value } \\
\text { of reference } \\
\text { rate } \\
\text { WOD }\end{array}$ \\
\hline $\mathrm{rk}_{1}$ & $\begin{array}{l}\text { Hardware } \\
\text { (server })\end{array}$ & {$[0,0,0,0] \%$} & {$[8,9,10,12] \%$} & $\begin{array}{l}\text { Number } \\
\text { of servers }\end{array}$ & 0 \\
\hline $\mathrm{rk}_{2}$ & $\begin{array}{l}\text { Implementation } \\
\text { service }\end{array}$ & {$[8,9,11,12] \%$} & $\begin{array}{l}\text { Number } \\
\text { of person-days }\end{array}$ & {$[60,65,78,80]$} \\
\hline $\mathrm{rk}_{3}$ & $\begin{array}{l}\text { Trainings } \\
{[0,0,0,0] \%}\end{array}$ & {$[0,08 ; 0,1 ; 0,13 ; 0,14] \%$} & $\begin{array}{l}\text { Number } \\
\text { of person-days }\end{array}$ & {$[55,58,60,65]$} \\
\hline $\mathrm{rk}_{4}$ & $\begin{array}{l}\text { System mainte- } \\
\text { nance }\end{array}$ & {$[10,12,18,25] \%$} & {$[0,0,0,0] \%$} & - & {$[0,0,0,0]$} \\
\hline
\end{tabular}

Table 2. DSS implementation undertaking model - example (source: self study)

\begin{tabular}{|c|c|c|c|c|c|}
\hline \multirow[b]{2}{*}{ CPG } & \multirow[b]{2}{*}{ Preparatory actions } & \multicolumn{2}{|c|}{ Event } & \multirow{2}{*}{$\begin{array}{l}\text { Duration } \\
\text { (days) }\end{array}$} & \multirow{2}{*}{$\begin{array}{c}\text { Preparatory } \\
\text { state SPG }\end{array}$} \\
\hline & & start & end & & \\
\hline $\operatorname{cpg}_{1}$ & $\begin{array}{l}\text { Preparation of test and development environment for } \\
\text { configuration and development works }\end{array}$ & 2 & 3 & {$[14,16,20,21]$} & 1 \\
\hline $\operatorname{cpg}_{2}$ & $\begin{array}{l}\text { Training of the design team using a demonstrating } \\
\text { version of the system }\end{array}$ & 3 & 4 & {$[24,26,30,32]$} & 0 \\
\hline $\operatorname{cpg}_{3}$ & Protection of technical infrastructure - servers & 2 & 4 & {$[45,50,62,70]$} & 1 \\
\hline $\operatorname{cpg}_{4}$ & $\begin{array}{l}\text { Preparation of computer network with the users' } \\
\text { computers }\end{array}$ & 4 & 8 & {$[50,55,70,80]$} & 1 \\
\hline $\operatorname{cpg}_{5}$ & Preparation of the data & 5 & 6 & {$[44,48,50,60]$} & 0 \\
\hline $\operatorname{cpg}_{6}$ & Data quality analysis & 6 & 8 & {$[14,16,21,25]$} & 0 \\
\hline $\operatorname{cpg}_{7}$ & Reorganization & 5 & 8 & {$[21,23,35,40]$} & 0 \\
\hline $\operatorname{cpg}_{8}$ & Training and control of final users & 8 & 9 & {$[8,9,12,14]$} & 0 \\
\hline CWE & Implementation and exploitation actions & & & & \\
\hline $\mathrm{cwe}_{1}$ & Planning of undertaking & 1 & 2 & {$[4,5,15,17]$} & \\
\hline $\mathrm{cwe}_{2}$ & Installation of the system & 4 & 6 & {$[12,14,15,16]$} & \\
\hline $\mathrm{cwe}_{3}$ & $\begin{array}{l}\text { Modelling of process in the system with the partici- } \\
\text { pation of the design team }\end{array}$ & 4 & 5 & {$[14,16,18,20]$} & \\
\hline $\mathrm{cwe}_{4}$ & Taking-over of the data & 6 & 7 & {$[12,14,16,17]$} & \\
\hline $\mathrm{cwe}_{5}$ & Testing actions & 7 & 8 & {$[10,11,12,14]$} & \\
\hline $\mathrm{cwe}_{6}$ & Preparation of the system activation and start-up & 9 & 10 & {$[8,9,12,14]$} & \\
\hline
\end{tabular}




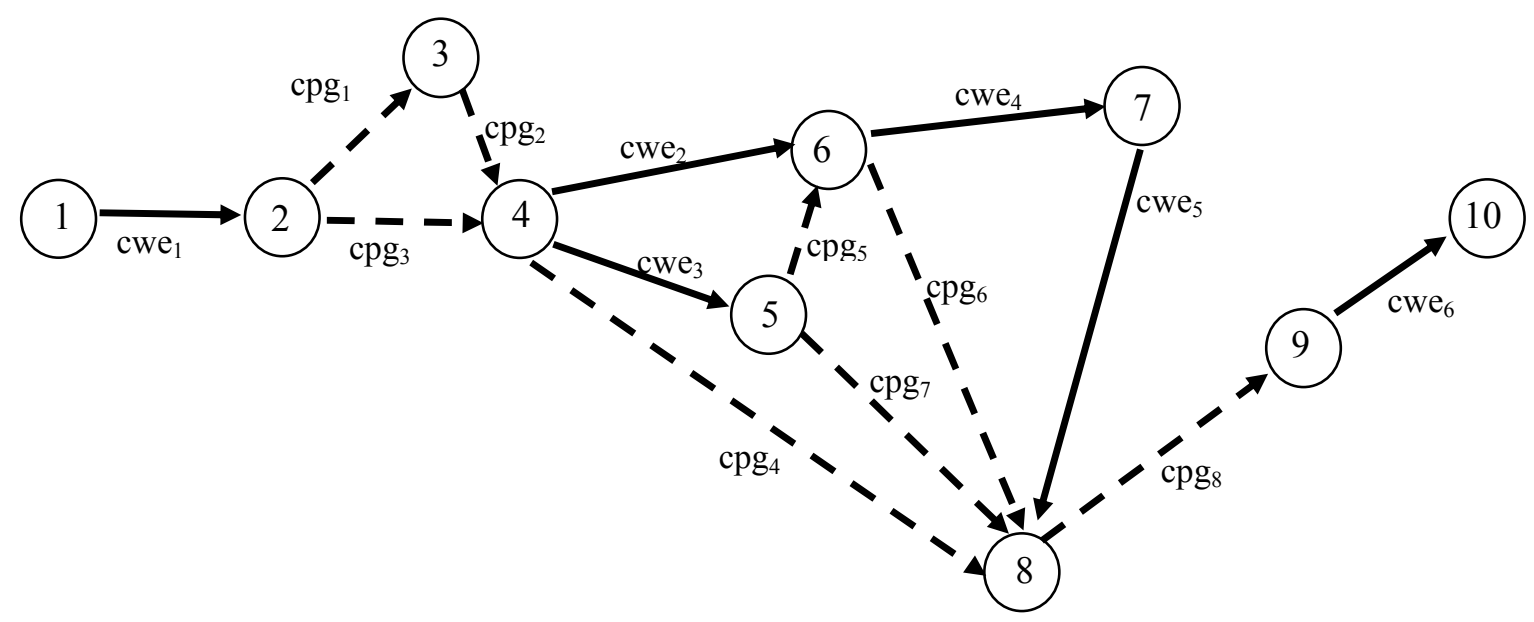

Figure 3. Implementation undertaking model - example

(source: self study)

Table 3. Values of indexes of the enterprise P before the commencement of DSS implementation - example (source: self study)

\begin{tabular}{|c|l|l|l|l|l|l|}
\hline & \multicolumn{1}{|c|}{$\mathrm{t}_{-1}$} & $\mathrm{t}_{0}$ & Start & $\mathrm{t}_{1}$ & $\ldots$ & $\mathrm{t}_{3}$ \\
\hline $\mathrm{W}_{1}$ & about $58=[54,58,58,60]$ & about $67=[63,67,67,69]$ & & $?$ & $?$ & $?$ \\
\hline $\mathrm{W}_{2}$ & about $65=[63,67,67,69]$ & about $72=[70,72,72,76]$ & & $?$ & $?$ & $?$ \\
\hline
\end{tabular}

An implementation undertaking model, determined by a set of preparatory actions for implementation CPG and implementation and exploitation actions CWE, connected with each other by means of technical, organizational and economical dependences, is given for every DSS under consideration as well. Every action is started and ended by an event and estimated duration determined imprecisely by means of fuzzy number is known for every action. An exemplary model of DSS implementation undertaking is presented in Table 2 and Figure 3.

Furthermore, an enterprise $\mathrm{P}$ considering an implementation of specified DSS is given.

A preparation state for the implementation SPG of the enterprise $\mathrm{P}$ before the commencement of implementation undertaking (moment $\mathrm{t}_{0}$ ) whose is also shown in Table 1 is given for every preparatory action CPG. The preparation state of given preparatory action assumes the value 0 when the action is not yet executed, and the value 1 when the action is already executed. A time period which is needed to realize a planned implementation undertaking depends on the preparation state of the enterprise for the implementation.

A vector of indexes $\mathrm{W}$, determining DSS implementation effects in the enterprise $\mathrm{P}$ is given, for example: $\mathrm{W}=\{$ delayed production orders ( $\%$ of realized orders $)$, overload (\% - maximum value of appearing overload, to level of $\%)\}$, and the values of indexes $\mathrm{W}$ are known before the commencement of planned implementation undertaking of specified DSS (for time moments $t=t_{-1}$, $t_{0}$ ). An example of imprecisely determined values of indexes $\mathrm{W}$ of the enterprise before the commencement of DSS implementation is presented in Table 3.

Furthermore, a vector $\mathrm{SF}(\mathrm{t})=\left\{\mathrm{SF}_{1}(\mathrm{t}), \ldots \mathrm{SF}_{\mathrm{h}}(\mathrm{t})\right\}$ determining a current and planned implementation state of functionalities $F=\left\{F_{1}, \ldots F_{h}\right\}$ of DSS in the enterprise $P$ in the time moments $t=t_{0}, t_{1}, \ldots t_{z}$ is given, and its values before the commencement of planned implementation of specified DSS are known. An example of implementation state SF of DSS with the functionalities $\mathrm{F}=\left\{\mathrm{F}_{1}, \mathrm{~F}_{2}, \mathrm{~F}_{3}, \mathrm{~F}_{4}, \mathrm{~F}_{5}\right\}=\{$ Basic data, Sales and distribution, Purchases, Materials management, Production $\}$ in the enterprise which plans to implement a functionality "Production" and uses other functionalities already is presented in Table 4.

A limited budget $\mathrm{B}$ of the enterprise $\mathrm{P}$ designed for the realization of planned implementation undertaking and time limit $\mathrm{T}$, preferred by the enterprise $\mathrm{P}$, related to the achievement of implementation undertaking effects of given DSS, within a specified exploitation period TE of this system is given as well. 
Table 4. Current and planned implementation state SF of functionalities $\mathrm{F}$ in a selected enterprise - example

\begin{tabular}{|c|c|c|c|c|c|c|}
\multicolumn{7}{c|}{ (source: self study) } \\
\hline & $\mathrm{t}_{-1}$ & $\mathrm{t}_{0}$ & Start & $\mathrm{t}_{1}$ & $\mathrm{t}_{2}$ & $\mathrm{t}_{3}$ \\
\hline $\mathrm{SF}_{1}$ & & 1 & & 1 & 1 & 1 \\
\hline $\mathrm{SF}_{2}$ & & 1 & & 1 & 1 & 1 \\
\hline $\mathrm{SF}_{3}$ & & 1 & & 1 & 1 & 1 \\
\hline $\mathrm{SF}_{4}$ & & 1 & & 1 & 1 & 1 \\
\hline $\mathrm{SF}_{5}$ & & 0 & & 1 & 1 & 1 \\
\hline
\end{tabular}

$\mathrm{A}$ vector $\mathrm{WE}=\left\{\mathrm{WE}_{1}, \ldots \mathrm{WE}_{\mathrm{k}}\right\}$ (of target criteria) of values of indexes $\mathrm{W}(\mathrm{t})=\left\{\mathrm{W}_{1}(\mathrm{t}), \mathrm{W}_{2}(\mathrm{t}), \ldots \mathrm{W}_{\mathrm{k}}(\mathrm{t})\right\}$ (for $t=T E$ ), preferred by the enterprise $P$, achieved after the implementation of specified DSS within a preferred time period $\mathrm{T}$, with the system exploitation period TE is also given. Exemplary values of indexes $\mathrm{W}=\left\{\mathrm{W}_{1}, \mathrm{~W}_{2}\right\}=\{$ delayed production orders $(\%$ of realized orders), overload (\% - maximum value of appearing overload, to level of $\%)\}$, preferred by the enterprise $\mathrm{P}$, achieved as a result of DSS implementation, amounting accordingly to: $\mathrm{WE}=\left\{\mathrm{WE}_{1}, \mathrm{WE}_{2}\right\}=\{$ "to about 15\%", "to about 10\%") is presented in Figure 4.

The experience of the enterprise $\mathrm{P}$ gained on the basis of implementation of other systems of DSS class, expressed by the values of indexes determining the effects of given implementation is also given. A general representation of such information related to a single implementation is included in Table 5.

Exemplary data from several realized implementations are presented in Table 6.

\section{The description of multi-criteria assessment methodology of implementation effectiveness}

The multi-criteria assessment methodology of decision support system implementation effectiveness (MAM DSS IME) consists of the following stages:
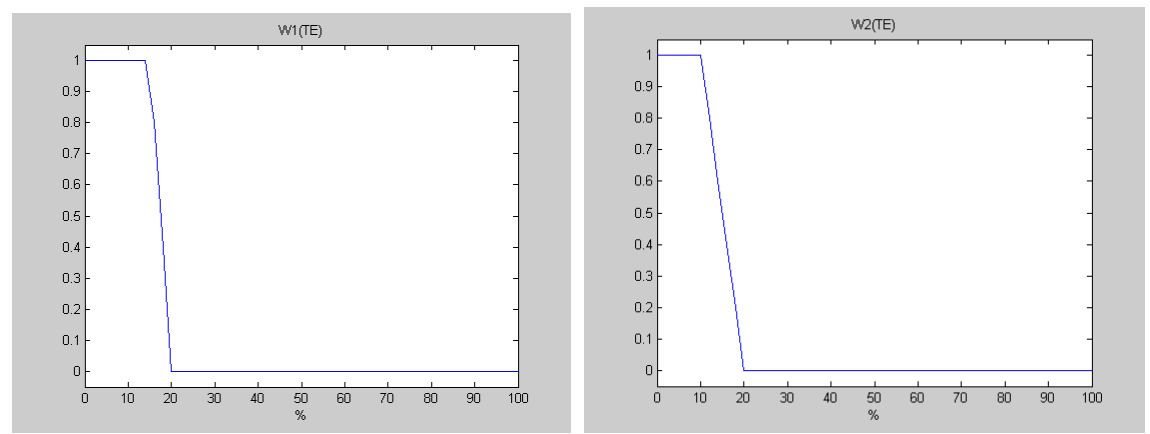

Figure 4. Values WE of indexes W, preferred by the enterprise, resulting from DSS implementation (source: self study)
- forecast of selected indexes of the enterprise from a DSS implementation on the basis of experiences from earlier executed implementations,

- forecast of implementation realization time and cost,

- multi-criteria assessment of DSS implementation effectiveness in relation to preferred target criteria.

\section{Stage 1}

The forecast of selected indexes of the enterprise from a DSS implementation takes place on the basis of the knowledge collected basing on earlier executed implementations. Therefore it is realized at two sub-stages:

1.1 first a base of empirical knowledge recorded in the form of fuzzy neural network, representing a fuzzy model of analysed reality, is formed,

1.2 then this base is used as a basis of forecasting, based on a fuzzy reasoning.

The forecast values of the enterprise's indexes which a planned DSS implementation allows to reach within a specified time limit are a result of this stage.

Stage 1.1 The formation of empirical knowledge base

A formation of empirical knowledge base is to generalise collected information from earlier realized implementations of other systems.

The identification of existing rules between the data from previous periods $t_{i-2}, t_{i-1}$ and a next period $t_{i}$, i.e. between the values of rates $\mathrm{W}\left(\mathrm{t}_{\mathrm{i}-2}\right) \mathrm{SF}\left(\mathrm{t}_{\mathrm{i}-1}\right) \mathrm{W}\left(\mathrm{t}_{\mathrm{i}-1}\right) \mathrm{SF}\left(\mathrm{t}_{\mathrm{i}}\right)$ and the values of indexes $\mathrm{W}\left(\mathrm{t}_{\mathrm{i}}\right)$ for $\mathrm{i}=1, \ldots \mathrm{z}$ is carried out on the basis of collected measurement data whose example is shown in Table 6. Table 7 presents the data from Table 6 prepared for the identification of modelled dependence rules. 
Table 5. Representation of implementation state of DSS functionalities and indexes of given enterprise (source: self study)

\begin{tabular}{|l|c|c|c|c|c|c|}
\hline \multicolumn{2}{|c|}{ Time } & $\mathrm{t}_{1}$ & $\mathrm{t}_{0}$ & $\mathrm{t}_{1}$ & $\ldots$ & $\mathrm{t}_{\mathrm{z}}$ \\
\hline \multirow{4}{*}{$\begin{array}{l}\text { Implementation state } \\
\text { of DSS functionalities }\end{array}$} & $\mathrm{SF}_{1}$ & & $\mathrm{SF}_{1}\left(\mathrm{t}_{0}\right)$ & $\mathrm{SF}_{1}\left(\mathrm{t}_{1}\right)$ & & $\mathrm{SF}_{1}\left(\mathrm{t}_{\mathrm{z}}\right)$ \\
\cline { 2 - 7 } & $\mathrm{SF}_{2}$ & & $\mathrm{SF}_{2}\left(\mathrm{t}_{0}\right)$ & $\mathrm{SF}_{2}\left(\mathrm{t}_{1}\right)$ & & $\mathrm{SF}_{2}\left(\mathrm{t}_{\mathrm{z}}\right)$ \\
\cline { 2 - 7 } & $\ldots$ & & & & & \\
\cline { 2 - 7 } & $\mathrm{SF}_{\mathrm{h}}$ & & $\mathrm{SF}_{\mathrm{h}}\left(\mathrm{t}_{0}\right)$ & $\mathrm{SF}_{\mathrm{h}}\left(\mathrm{t}_{1}\right)$ & & $\mathrm{SF}_{\mathrm{h}}\left(\mathrm{t}_{\mathrm{z}}\right)$ \\
\hline \multirow{4}{*}{$\begin{array}{l}\text { Indexes } \\
\text { of enterprise }\end{array}$} & $\mathrm{W}_{1}$ & $\mathrm{~W}_{1}\left(\mathrm{t}_{1}\right)$ & $\mathrm{W}_{1}\left(\mathrm{t}_{0}\right)$ & $\mathrm{W}_{1}\left(\mathrm{t}_{1}\right)$ & & $\mathrm{W}_{1}\left(\mathrm{t}_{\mathrm{z}}\right)$ \\
\cline { 2 - 7 } & $\mathrm{W}_{2}$ & $\mathrm{~W}_{2}\left(\mathrm{t}_{1}\right)$ & $\mathrm{W}_{2}\left(\mathrm{t}_{0}\right)$ & $\mathrm{W}_{2}\left(\mathrm{t}_{1}\right)$ & & $\mathrm{W}_{2}\left(\mathrm{t}_{\mathrm{z}}\right)$ \\
\cline { 2 - 7 } & $\ldots$ & & & & & \\
\cline { 2 - 7 } & $\mathrm{W}_{\mathrm{k}}$ & $\mathrm{W}_{\mathrm{k}}\left(\mathrm{t}_{\mathrm{l}}\right)$ & $\mathrm{W}_{\mathrm{k}}\left(\mathrm{t}_{0}\right)$ & $\mathrm{W}_{\mathrm{k}}\left(\mathrm{t}_{1}\right)$ & & $\mathrm{W}_{\mathrm{k}}\left(\mathrm{t}_{\mathrm{z}}\right)$ \\
\hline
\end{tabular}

Table 6. Exemplary data from realized implementations of systems of DSS class (source: self study)

\begin{tabular}{|c|c|c|c|c|c|c|c|c|c|c|}
\hline & \multicolumn{7}{|c|}{ Implementation 1 } & \multicolumn{5}{c|}{ Implementation 2} \\
\hline & $\mathrm{t}_{-1}$ & $\mathrm{t}_{0}$ & $\mathrm{t}_{1}$ & $\mathrm{t}_{2}$ & $\mathrm{t}_{3}$ & $\mathrm{t}_{-1}$ & $\mathrm{t}_{0}$ & $\mathrm{t}_{1}$ & $\mathrm{t}_{2}$ & $\mathrm{t}_{3}$ \\
\hline $\mathrm{SF}_{1}$ & & 1 & 1 & 1 & 1 & & 1 & 1 & 1 & 1 \\
\hline $\mathrm{SF}_{2}$ & & 0 & 1 & 1 & 1 & & 0 & 1 & 1 & 1 \\
\hline $\mathrm{SF}_{3}$ & & 0 & 0 & 1 & 1 & & 0 & 0 & 0 & 1 \\
\hline $\mathrm{W}_{1}$ & $60 \%$ & $70 \%$ & $30 \%$ & $20 \%$ & $18 \%$ & $78 \%$ & $72 \%$ & $27 \%$ & $25 \%$ & $22 \%$ \\
\hline $\mathrm{W}_{2}$ & $90 \%$ & $80 \%$ & $35 \%$ & $25 \%$ & $24 \%$ & $60 \%$ & $68 \%$ & $18 \%$ & $15 \%$ & $12 \%$ \\
\hline \multicolumn{8}{|c|}{ Implementation 3} & \multicolumn{7}{c|}{ Implementation 4} \\
\hline $\mathrm{SF}_{1}$ & $\mathrm{t}_{-1}$ & $\mathrm{t}_{0}$ & $\mathrm{t}_{1}$ & $\mathrm{t}_{2}$ & $\mathrm{t}_{3}$ & $\mathrm{t}_{-1}$ & $\mathrm{t}_{0}$ & $\mathrm{t}_{1}$ & $\mathrm{t}_{2}$ & $\mathrm{t}_{3}$ \\
\hline $\mathrm{SF}_{2}$ & & 1 & 1 & 1 & 1 & & 1 & 1 & 1 & 1 \\
\hline $\mathrm{SF}_{3}$ & & 0 & 1 & 1 & 1 & & 0 & 1 & 1 & 1 \\
\hline $\mathrm{W}_{1}$ & $55 \%$ & $63 \%$ & $34 \%$ & $31 \%$ & $26 \%$ & $50 \%$ & $65 \%$ & $26 \%$ & $15 \%$ & $16 \%$ \\
\hline $\mathrm{W}_{2}$ & $71 \%$ & $82 \%$ & $31 \%$ & $27 \%$ & $17 \%$ & $70 \%$ & $60 \%$ & $18 \%$ & $10 \%$ & $8 \%$ \\
\hline
\end{tabular}

Table 7. Measurement data prepared for modelling. Source: authors' own research (source: self study)

\begin{tabular}{|c|c|c|c|c|c|c|c|c|c|c|c|c|}
\hline & \multicolumn{3}{|c|}{ Implementation 1 } & \multicolumn{3}{c|}{ Implementation 2 } & \multicolumn{3}{c|}{ Implementation 3 } & \multicolumn{3}{|c|}{ Implementation 4 } \\
\hline $\mathrm{W}_{1}\left(\mathrm{t}_{\mathrm{i}-2}\right)$ & 0,60 & 0,70 & 0,30 & 0,78 & 0,72 & 0,27 & 0,55 & 0,63 & 0,34 & 0,50 & 0,65 & 0,26 \\
\hline $\mathrm{W}_{2}\left(\mathrm{t}_{\mathrm{i}-2}\right)$ & 0,90 & 0,80 & 0,35 & 0,60 & 0,68 & 0,18 & 0,71 & 0,82 & 0,31 & 0,70 & 0,60 & 0,18 \\
\hline $\mathrm{SF}_{1}\left(\mathrm{t}_{\mathrm{i}-1}\right)$ & 1 & 1 & 1 & 1 & 1 & 1 & 1 & 1 & 1 & 1 & 1 & 1 \\
\hline $\mathrm{SF}_{2}\left(\mathrm{t}_{\mathrm{i}-1}\right)$ & 0 & 1 & 1 & 0 & 1 & 1 & 0 & 1 & 1 & 0 & 1 & 1 \\
\hline $\mathrm{SF}_{3}\left(\mathrm{t}_{\mathrm{i}-1}\right)$ & 0 & 0 & 1 & 0 & 0 & 0 & 0 & 0 & 0 & 0 & 0 & 1 \\
\hline $\mathrm{W}_{1}\left(\mathrm{t}_{\mathrm{i}-1}\right)$ & 0,70 & 0,30 & 0,20 & 0,72 & 0,27 & 0,25 & 0,63 & 0,34 & 0,31 & 0,65 & 0,26 & 0,15 \\
\hline $\mathrm{W}_{2}\left(\mathrm{t}_{\mathrm{i}-1}\right)$ & 0,80 & 0,35 & 0,25 & 0,68 & 0,18 & 0,15 & 0,82 & 0,31 & 0,27 & 0,60 & 0,18 & 0,10 \\
\hline $\mathrm{SF}_{1}\left(\mathrm{t}_{\mathrm{i}}\right)$ & 1 & 1 & 1 & 1 & 1 & 1 & 1 & 1 & 1 & 1 & 1 & 1 \\
\hline $\mathrm{SF}_{2}\left(\mathrm{t}_{\mathrm{i}}\right)$ & 1 & 1 & 1 & 1 & 1 & 1 & 1 & 1 & 1 & 1 & 1 & 1 \\
\hline $\mathrm{SF}_{3}\left(\mathrm{t}_{\mathrm{i}}\right)$ & 0 & 1 & 1 & 0 & 0 & 1 & 0 & 0 & 1 & 0 & 1 & 1 \\
\hline $\mathrm{W}_{1}\left(\mathrm{t}_{\mathrm{i}}\right)$ & 0,30 & 0,20 & 0,18 & 0,27 & 0,25 & 0,22 & 0,34 & 0,31 & 0,26 & 0,26 & 0,15 & 0,16 \\
\hline $\mathrm{W}_{2}\left(\mathrm{t}_{\mathrm{i}}\right)$ & 0,35 & 0,25 & 0,24 & 0,18 & 0,15 & 0,12 & 0,31 & 0,27 & 0,17 & 0,18 & 0,10 & 0,08 \\
\hline
\end{tabular}


Stage 1.1 - Step 1 The filtration of measurement samples by means of fuzzy average diagram method

The filtration of measurement samples of modelled system input/output lies in the determination of essential inputs of the model by means of below-discussed method of fuzzy average diagrams prepared by Lin and Cunningham (see [3], [4]).

All measurement samples are projected on planes of particular input variables for every output variable. Then a weighted average for any section of given input variable on the basis of measurement samples of the nearest neighbourhood using a Gaussian affinity function according to the formula (1) is calculated.

If a value of output variable depends on an input variable, then the average in sections changes. The higher dependence of output variable on a given input variable, the bigger scope of average value variability for analysed sections.

$$
\mathrm{y}_{\mathrm{sr}}(\mathrm{x})=\frac{\sum_{\mathrm{k}=1}^{\mathrm{m}} \mu\left(\mathrm{x}_{\mathrm{k}}\right) \mathrm{y}_{\mathrm{k}}}{\sum_{\mathrm{k}=1}^{\mathrm{m}} \mu\left(\mathrm{x}_{\mathrm{k}}\right)}=\frac{\sum_{\mathrm{k}=1}^{\mathrm{m}} \exp \left(-\left(\frac{\mathrm{x}_{\mathrm{k}}-\mathrm{x}}{\mathrm{b}}\right)^{2}\right) \mathrm{y}_{\mathrm{k}}}{\sum_{\mathrm{k}=1}^{\mathrm{m}} \exp \left(-\left(\frac{\mathrm{x}_{\mathrm{k}}-\mathrm{x}}{\mathrm{b}}\right)^{2}\right)}
$$

where:

$x$-input variable,

$y$ - output variable,

$k$ - number of measurement point,

$b$ - width of neighbourhood scope in section points.

A parameter $\mathrm{b}$ equal to $10 \%$ of variability scope of given input variable is assumed in the study. For example, for the data from Table 7 in case of input variable $\mathrm{W}_{1}\left(\mathrm{t}_{\mathrm{i}-2}\right)=\mathrm{x}$ and output variable $\mathrm{W}_{1}\left(\mathrm{t}_{\mathrm{i}}\right)=\mathrm{y}$, the parameter $\mathrm{b}$ is $\mathrm{b}=10 \%(0,78-0,26)=0,052$ and the determination of average value $\mathrm{y}_{\mathrm{av}}$ in the point 0,6 is presented in Table 8.

The values of the average $\mathrm{y}_{\mathrm{av}}$ determined in other measurement points are included in Table 9. On the basis of the data from Table 9 it can be noticed that a scope of section average variability in this case is equal to $\Delta \mathrm{y}_{\mathrm{av}}=0,31-0,19=0,12$.

After the filtration for other measurement data from Table 7, executed by means of proposed method, there are obtained the results included in Table 10 from which it results that the variables marked as: $x_{1}, x_{2}, x_{3}$, $\mathrm{x}_{4}, \mathrm{x}_{5}, \mathrm{x}_{6}, \mathrm{x}_{7}$ are essential inputs for modelling.

The measurement data, obtained as a result of this stage, prepared for modelling the dependence between output variables $\left(\mathrm{y}_{1}, \mathrm{y}_{2}\right)$ and input variables $\left(\mathrm{x}_{1}, \ldots \mathrm{x}_{7}\right)$, are presented in Table 11.

Stage 1.1 - Step 2 The self-organization and adjustment of fuzzy model parameters by a geometrical method of maximum absolute error points

In this step the measurement data of the most important elements of fuzzy model structure which include: rule base and number of fuzzy sets assigned to individual inputs and outputs of the model are determined on the basis of the data prepared in the step 1. For this purpo se it is used a modelling algorithm by the method of maximum error point (see Piegat 1999, Piegat 2001) whose conduct course is presented below on the basis of simplified example of modelling of the function for which the measurement data included in Table 12 are known.

Table 8 . Determination of average value $\mathrm{y}_{\mathrm{av}}(0,6)$

(source: self study)

\begin{tabular}{|c|c|c|c|c|c|c|c|c|c|c|c|c|c|}
\hline $\mathrm{x}$ & 0,6 & 0,7 & 0,3 & 0,78 & 0,72 & 0,27 & 0,55 & 0,63 & 0,34 & 0,5 & 0,65 & 0,26 & \\
\hline $\mathrm{y}$ & 0,3 & 0,2 & 0,18 & 0,27 & 0,25 & 0,22 & 0,34 & 0,31 & 0,26 & 0,26 & 0,15 & 0,16 & total \\
\hline$\mu\left(\mathrm{x}_{\mathrm{k}}\right)$ & 1 & 0,025 & 0 & 0 & 0 & 0 & 0,40 & 0,72 & 0 & 0,02 & 0,40 & 0 & 2,56 \\
\hline$\mu\left(\mathrm{x}_{\mathrm{k}}\right) \mathrm{y}_{\mathrm{k}}$ & 0,3 & 0,005 & 0 & 0 & 0 & 0 & 0,13 & 0,22 & 0 & 0,01 & 0,06 & 0 & 0,73 \\
\hline & & & & & & & & & & & & $\mathrm{y}_{\mathrm{av}}$ & 0,28 \\
\hline
\end{tabular}

Table 9. Determination of average value $\mathrm{y}_{\mathrm{av}}$ in measurement points $\mathrm{x}_{1}$

(source: self study)

\begin{tabular}{|c|c|c|c|c|c|c|c|c|c|c|c|c|}
\hline $\mathrm{x}_{1}$ & 0,6 & 0,7 & 0,3 & 0,78 & 0,72 & 0,27 & 0,55 & 0,63 & 0,34 & 0,5 & 0,65 & 0,26 \\
\hline $\mathrm{y}_{1}$ & 0,3 & 0,2 & 0,18 & 0,27 & 0,25 & 0,22 & 0,34 & 0,31 & 0,26 & 0,26 & 0,15 & 0,16 \\
\hline $\mathrm{y}_{\text {śr }}$ & 0,28 & 0,22 & 0,20 & 0,26 & 0,23 & 0,19 & 0,31 & 0,25 & 0,23 & 0,28 & 0,23 & 0,19 \\
\hline
\end{tabular}


Table 10. Results of filtration by means of fuzzy average diagram method for the data from Table 7 (source: self study)

\begin{tabular}{|c|c|c|c|}
\hline & \multicolumn{2}{|c|}{$\Delta \mathrm{y}_{\text {jav }}$} & $\begin{array}{c}\text { Essential } \\
\text { variables }\end{array}$ \\
\hline & $\mathrm{W}_{1}\left(\mathrm{t}_{\mathrm{i}}\right)=\mathrm{y}_{1}$ & $\mathrm{~W}_{2}\left(\mathrm{t}_{\mathrm{i}}\right)=\mathrm{y}_{2}$ & input \\
\hline $\mathrm{W}_{1}\left(\mathrm{t}_{\mathrm{i}-2}\right)$ & 0,1212 & 0,1547 & $\mathrm{x}_{1}$ \\
\hline $\mathrm{W}_{2}\left(\mathrm{t}_{\mathrm{i}-2}\right)$ & 0,1006 & 0,2220 & $\mathrm{x}_{2}$ \\
\hline $\mathrm{SF}_{1}\left(\mathrm{t}_{\mathrm{i}-1}\right)$ & 0 & 0 & - \\
\hline $\mathrm{SF}_{2}\left(\mathrm{t}_{\mathrm{i}-1}\right)$ & 0,0763 & 0,0825 & $\mathrm{x}_{3}$ \\
\hline $\mathrm{SF}_{3}\left(\mathrm{t}_{\mathrm{i}-1}\right)$ & 0,0860 & 0,0480 & $\mathrm{x}_{4}$ \\
\hline $\mathrm{W}_{1}\left(\mathrm{t}_{\mathrm{i}-1}\right)$ & 0,1326 & 0,1273 & $\mathrm{x}_{5}$ \\
\hline $\mathrm{W}_{2}\left(\mathrm{t}_{\mathrm{i}-1}\right)$ & 0,1327 & 0,2234 & $\mathrm{x}_{6}$ \\
\hline $\mathrm{SF}_{1}\left(\mathrm{t}_{\mathrm{i}}\right)$ & 0 & 0 & - \\
\hline $\mathrm{SF}_{2}\left(\mathrm{t}_{\mathrm{i}}\right)$ & 0 & 0 & - \\
\hline $\mathrm{SF}_{3}\left(\mathrm{t}_{\mathrm{i}}\right)$ & 0,0933 & 0,0800 & $\mathrm{x}_{7}$ \\
\hline
\end{tabular}

Table 11. Measurement data from Table 7 after filtration (source: self study)

\begin{tabular}{|c|c|c|c|c|c|c|c|c|c|c|c|c|c|}
\hline & & \multicolumn{3}{|c|}{ Implementation 1 } & \multicolumn{3}{|c|}{ Implementation 2 } & \multicolumn{3}{|c|}{ Implementation 3 } & \multicolumn{3}{|c|}{ Implementation 4 } \\
\hline $\mathrm{x}_{1}$ & $\mathrm{~W}_{1}\left(\mathrm{t}_{\mathrm{i}-2}\right)$ & 0,60 & 0,70 & 0,30 & 0,78 & 0,72 & 0,27 & 0,55 & 0,63 & 0,34 & 0,50 & 0,65 & 0,26 \\
\hline $\mathrm{x}_{2}$ & $\mathrm{~W}_{2}\left(\mathrm{t}_{\mathrm{i}-2}\right)$ & 0,90 & 0,80 & 0,35 & 0,60 & 0,68 & 0,18 & 0,71 & 0,82 & 0,31 & 0,70 & 0,60 & 0,18 \\
\hline $\mathrm{x}_{3}$ & $\mathrm{SF}_{2}\left(\mathrm{t}_{\mathrm{i}-1}\right)$ & 0 & 1 & 1 & 0 & 1 & 1 & 0 & 1 & 1 & 0 & 1 & 1 \\
\hline $\mathrm{x}_{4}$ & $\mathrm{SF}_{3}\left(\mathrm{t}_{\mathrm{i}-1}\right)$ & 0 & 0 & 1 & 0 & 0 & 0 & 0 & 0 & 0 & 0 & 0 & 1 \\
\hline $\mathrm{x}_{5}$ & $\mathrm{~W}_{1}\left(\mathrm{t}_{\mathrm{i}-1}\right)$ & 0,70 & 0,30 & 0,20 & 0,72 & 0,27 & 0,25 & 0,63 & 0,34 & 0,31 & 0,65 & 0,26 & 0,15 \\
\hline $\mathrm{x}_{6}$ & $\mathrm{~W}_{2}\left(\mathrm{t}_{\mathrm{i}-1}\right)$ & 0,80 & 0,35 & 0,25 & 0,68 & 0,18 & 0,15 & 0,82 & 0,31 & 0,27 & 0,60 & 0,18 & 0,10 \\
\hline $\mathrm{x}_{7}$ & $\mathrm{SF}_{3}\left(\mathrm{t}_{\mathrm{i}}\right)$ & 0 & 1 & 1 & 0 & 0 & 1 & 0 & 0 & 1 & 0 & 1 & 1 \\
\hline $\mathrm{y}_{1}$ & $\mathrm{~W}_{1}\left(\mathrm{t}_{\mathrm{i}}\right)$ & 0,30 & 0,20 & 0,18 & 0,27 & 0,25 & 0,22 & 0,34 & 0,31 & 0,26 & 0,26 & 0,15 & 0,16 \\
\hline $\mathrm{y}_{2}$ & $\mathrm{~W}_{2}\left(\mathrm{t}_{\mathrm{i}}\right)$ & 0,35 & 0,25 & 0,24 & 0,18 & 0,15 & 0,12 & 0,31 & 0,27 & 0,17 & 0,18 & 0,10 & 0,08 \\
\hline
\end{tabular}

Table 12. Exemplary measurement data of function $\mathrm{y} 1=\mathrm{x} 12$

(source: self study)

\begin{tabular}{|c|c|c|c|c|c|c|c|c|c|c|c|c|c|c|}
\hline $\mathrm{x}_{1}$ & -2 & $-1,7$ & $-1,4$ & $-1,1$ & $-0,8$ & $-0,5$ & $-0,2$ & 0,1 & 0,4 & 0,7 & 1 & 1,3 & 1,6 & 1,9 \\
\hline $\mathrm{y}_{1}$ & 4 & 2,89 & 1,96 & 1,21 & 0,64 & 0,25 & 0,04 & 0,01 & 0,16 & 0,49 & 1 & 1,69 & 2,56 & 3,61 \\
\hline
\end{tabular}

\section{A The determination of base model $M_{0}$ by}

\section{a method of exit beyond the space of considerations}

In case of $n$ input variables, a base model which constitutes the most rough generalization of modelled dependence takes a form of hypertetrahedral model of $n+1$ rules. In case of three input variables, this model is reduced to the tetrahedral space placed in Figure 5 with four rules placed in the points $\mathrm{P}_{1}, \ldots \mathrm{P}_{4}$.

In case of two input variables, it has a triangular form, and in case of one input variable $\mathrm{x}_{1}$ it is sufficient to place the rules in measurement points of minimum and maximum value of this input variable, i.e. for an example of the data from Table 12 in the points of $\mathrm{x}_{1}=-2$ and $\mathrm{x}_{1}=1,9$.
The values of output variable are established at random at this stage, therefore the points for the initial rules of the example under consideration are: $(-2 ; 0,01)$ and $(1,9 ; 4)$. These points determine the parameters of affinity function of input $\mathrm{x}_{1}$, assumed in the base model, which are shown in Figure $6 a)\left(a_{11}=-2, a_{12}=1,9\right)$, and the parameters of affinity function of output $\mathrm{y}_{1}$, which are shown in Figure $6 \mathrm{~b})\left(\mathrm{yB}_{11}=0,01, \mathrm{yB}_{21}=4\right)$.

It is assumed that the inference is performed using an operator of PROD implication, and defuzzification is performed by means of height method (using singletons placed on vertices of affinity function) in the base model. 


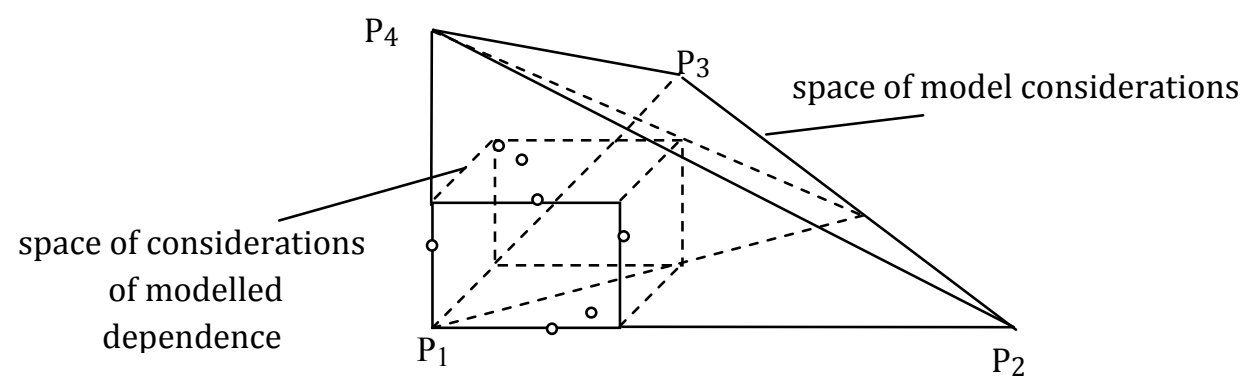

Figure 5. Exit beyond the space of considerations - example for three input variables (source: self study)
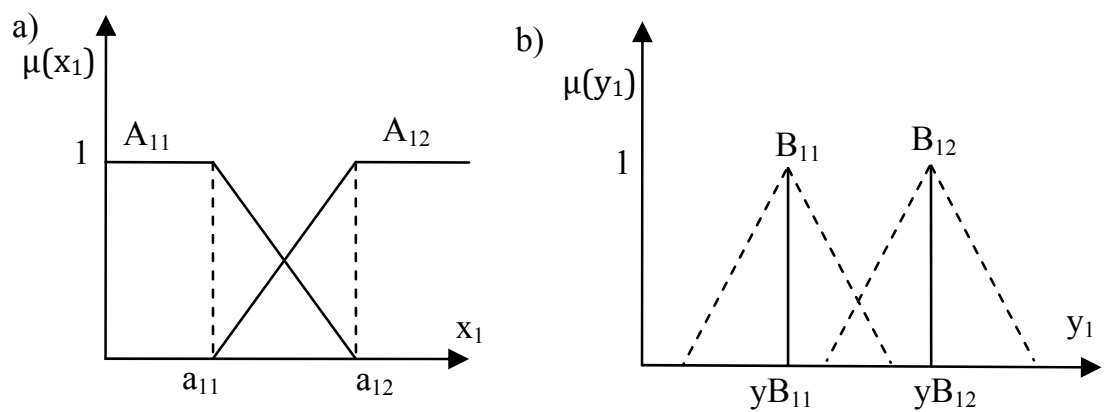

Figure 6. Affinity functions of fuzzy model (source: self study)

\section{B A fuzzy neural network representing a base model for the case of three input variables and two output variables is presented in Figure 7}

In an analysed example with one input variable and one output variable, this network is reduced to the input $\mathrm{x}_{1}$ and output $\mathrm{y}_{1}$. In the course of training of neural network, the parameters of affinity function of model outputs are subject to the adjustment, therefore in the example under consideration there are the parameters $\mathrm{yB}_{11}$ and $\mathrm{yB}_{21}$.

The adjustment, discussed below more precisely, is executed according to the rule of error back propagation and gradient methods. It consists in such a gradual change of parameters adjusted on the basis of measurement data which leads to the minimization of a criterion which is an accumulated squared error. A set of training samples and a set of test samples is separated among all measurement samples. The samples are divided randomly in the ration of 2 to 1 .

For every measurement $\mathrm{g}$ from the set of training data there are calculated a value of model output $\mathrm{y}_{\mathrm{M} 0}(\mathrm{~g})$ and error:

$$
\mathrm{e}(\mathrm{g})=\mathrm{y}(\mathrm{g})-\mathrm{y}_{\mathrm{M} 0}(\mathrm{~g})
$$

The accumulated squared error of the network for the whole training cycle (epoch) with $\mathrm{k}$ output variables is equal to:

$$
\mathrm{E}=\left[\begin{array}{c}
\mathrm{E}_{1} \\
\vdots \\
\mathrm{E}_{\mathrm{k}}
\end{array}\right]=0,5\left[\begin{array}{c}
\sum_{\mathrm{g}} \mathrm{e}_{1}(\mathrm{~g})^{2} \\
\vdots \\
\sum_{\mathrm{g}} \mathrm{e}_{\mathrm{k}}(\mathrm{g})^{2}
\end{array}\right]
$$

The impact of adjusted parameter $\mathrm{y}_{\mathrm{Bij}}(\mathrm{g})(\mathrm{i}=1, \ldots \mathrm{n}+1$ $\mathrm{j}=1, \ldots \mathrm{k}, \mathrm{n}$ - number of input variables, $\mathrm{k}$ - number of output variables) in the step $g$ on an error of the network depends on a derivate $20,5\left(\mathrm{e}_{\mathrm{j}}(\mathrm{g})\right) 2 / \partial \mathrm{y}_{\mathrm{Bij}}(\mathrm{g})$. To bring a parameter closer to its optimum value it is moved in the direction of a negative gradient by the value $\Delta \mathrm{y}_{\mathrm{Bij}}(\mathrm{g}+1)$ expressed by the formula:

$$
\Delta \mathrm{y}_{B \mathrm{Bj}}(\mathrm{g}+1)=-0,5 \alpha \frac{\partial 0,5\left(\mathrm{e}_{\mathrm{j}}(\mathrm{g})\right)^{2}}{\partial \mathrm{y}_{\mathrm{Bij}}(\mathrm{g})}
$$

where:

$\alpha-$ training speed coefficient. 
A new value of parameter $\mathrm{y}_{\mathrm{Bij}}(\mathrm{g}+1)$ is calculated on the basis of the formula

$$
\begin{aligned}
& \mathrm{y}_{B i j}(\mathrm{~g}+1)=\mathrm{y}_{B i j}(\mathrm{~g})+\Delta \mathrm{y}_{B i j}(\mathrm{~g}+1)= \\
& \mathrm{y}_{B \mathrm{Bij}}(\mathrm{g})-0,5 \alpha \frac{\partial 0,5\left(\mathrm{e}_{\mathrm{j}}(\mathrm{g})\right)^{2}}{\partial \mathrm{y}_{\mathrm{Bij}}(\mathrm{g})}
\end{aligned}
$$

where:

$$
\frac{\partial 0,5\left(e_{j}(g)\right)^{2}}{\partial y_{B i j}(g)}=\frac{-\mu_{B i}(g)}{\mu_{B 1}(g)+\ldots+\mu_{B n+1}(g)} e_{j}(g)
$$

The network is trained on the basis of training data, then an average absolute error is determined on the basis of test data, and after the execution of a series of experiments, these values of adjusted parameters are selected with which the error on the test data is the least.

Going back to the analysed example related to the data from Table 12, a division into training data and test data, shown in Table 13, is assumed in this study.

As a result of executed experiments with such an assumed division of measurement data, the values of adjusted parameters $y B_{11}=2,8022 y B_{21}=0,7703$ with an average absolute error on the training data $a v E_{\mathbf{0} u}=1,5565$, and on the test data $a v E_{\mathbf{0} t}=0,7066$ are obtained.

Table 13. Division of measurement data from Table 12 into training data $\left(\mathrm{x}_{1} \mathrm{u}, \mathrm{y}_{1} \mathrm{u}\right)$ and test data $\left(\mathrm{x}_{1} \mathrm{t}, \mathrm{y}_{1} \mathrm{t}\right)$ (source: self study)

\begin{tabular}{|l|r|r|r|r|r|r|r|r|r|}
\hline $\mathrm{x}_{1} \mathrm{u}$ & $-2,00$ & $-1,40$ & $-1,10$ & $-0,50$ & $-0,20$ & 0,10 & 0,40 & 1,60 & 1,90 \\
\hline $\mathrm{y}_{1} \mathrm{u}$ & 4,00 & 1,96 & 1,21 & 0,25 & 0,04 & 0,01 & 0,16 & 2,56 & 3,61 \\
\hline $\mathrm{x}_{1} \mathrm{t}$ & $-1,70$ & $-0,80$ & 0,70 & 1,00 & 1,30 & & & & \\
\hline $\mathrm{y}_{1} \mathrm{t}$ & 2,89 & 0,64 & 0,49 & 1,00 & 1,69 & & & & \\
\hline
\end{tabular}

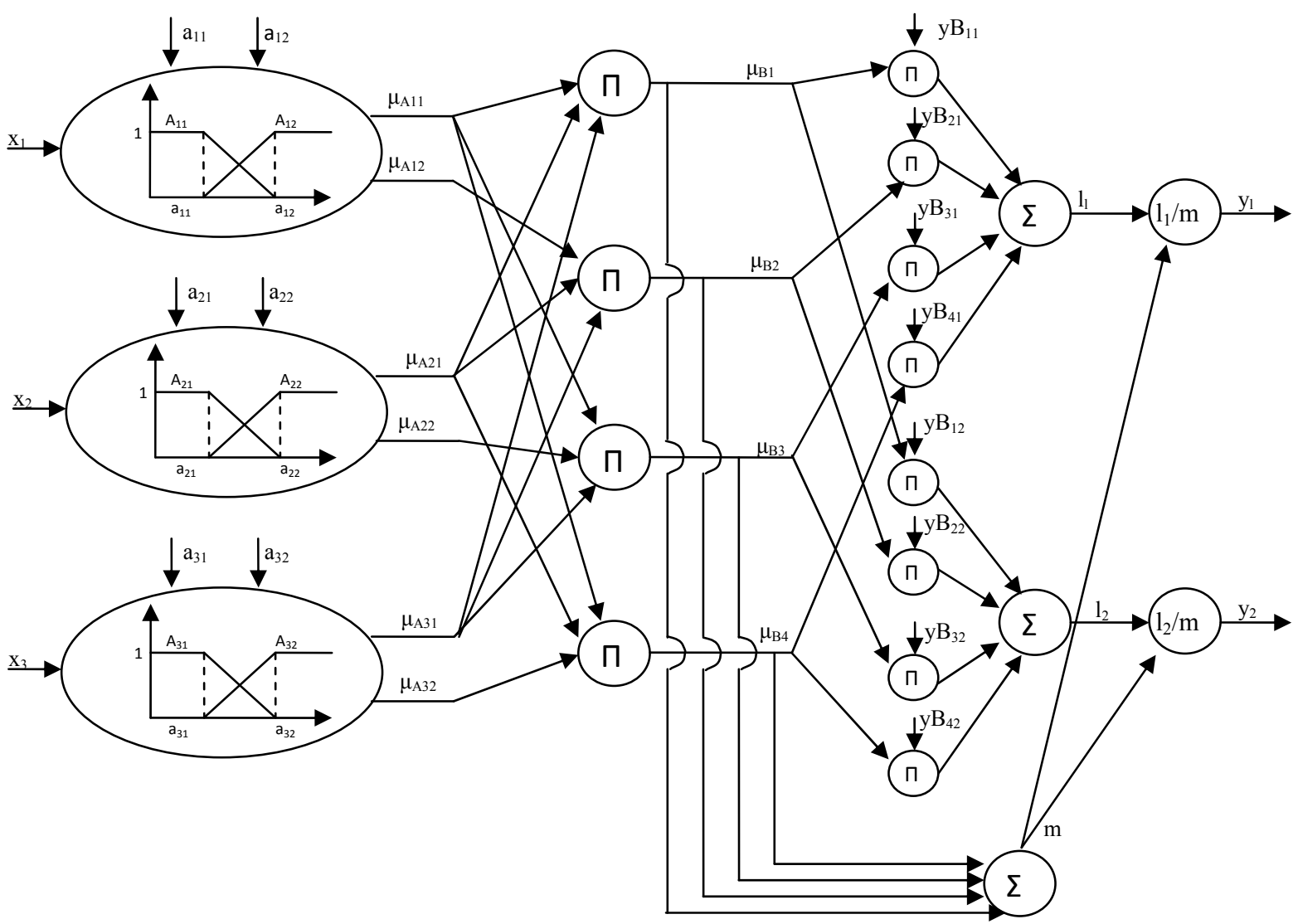

Figure 7. Fuzzy neural network representing a base model (source: self study) 
Table 14. Base model error

(source: self study)

\begin{tabular}{|c|r|r|r|r|r|r|r|r|r|}
\hline $\mathrm{x}_{1} \mathrm{u}$ & $-2,0000$ & $-1,4000$ & $-1,1000$ & $-0,5000$ & $-0,2000$ & 0,1000 & 0,4000 & 1,6000 & 1,9000 \\
\hline $\mathrm{y}_{1} \mathrm{u}$ & 4,0000 & 1,9600 & 1,2100 & 0,2500 & 0,0400 & 0,0100 & 0,1600 & 2,5600 & 3,6100 \\
\hline $\mathrm{y}_{1 \mathrm{M} 0} \mathrm{u}$ & 2,8022 & 2,4896 & 2,3333 & 2,0207 & 1,8644 & 1,7081 & 1,5518 & 0,9266 & 0,7703 \\
\hline $\mathrm{E}_{0} \mathrm{u}$ & 1,1978 & $-0,5296$ & $-1,1233$ & $-1,7707$ & $-1,8244$ & $-1,6981$ & $-1,3918$ & 1,6334 & 2,8397 \\
\hline
\end{tabular}

\section{The determination of base model error $\mathbf{E}_{0}$}

In case of sufficient precision - completion of modelling, otherwise - continuation of modelling (stage D modelling of error $E_{0}$ ). The precision of base model $M_{0}$ is controlled by comparing output values of the model and measurement data. The base model error $\mathrm{E}_{0} \mathrm{u}=\mathrm{y}_{1} \mathrm{u}-$ $\mathrm{y}_{1 \mathrm{M} 0} \mathrm{u}$ is shown in Table 14. The average absolute error:

$$
\operatorname{avE}_{0} u=\sum_{i=1}^{9}\left|E_{0} u_{i}\right| / 9=1,5565
$$

Modelling was continued going to the stage D.

D Placing 2 rules in points of the extreme of base model error $E_{0}$ - model of error $E_{0 M}$

When the error $\mathrm{E}_{\mathbf{0}}$ is determined, there are placed additional rules in the points of the extreme (visible in Table 14), i.e. in the points: $(1,9 ; 2,8397)=\left(\mathrm{m}^{1}{ }_{11}, \mathrm{e}_{0 \max 1}\right)$ and $(-0,2 ;-1,8244)=\left(\mathrm{m}_{12}^{1}, \mathrm{e}_{0 \min 1}\right)$.

\section{E The adjustment of affinity function parameters of error model $E_{0 M}$ on the basis of samples of base model error $\mathbf{E}_{\mathbf{0}}$}

The error is modelled by the affinity functions of the form (7), shown in Figure 8.

$$
\mu_{\mathrm{AEE} 1 \mathrm{~s}}^{1}\left(\mathrm{x}_{1}\right)=\exp \left(-\left|\frac{\mathrm{x}_{1}-\mathrm{m}_{1 \mathrm{~s}}^{1}}{\delta_{1 \mathrm{~s}}^{1}}\right|^{1_{1 \mathrm{~s}}^{1}}\right) \quad \mathrm{s}=1,2
$$

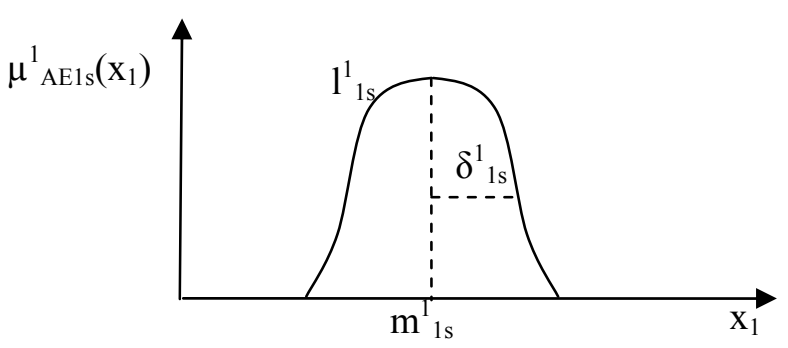

Figure 8. Affinity function for modelling the error $\mathrm{E}_{0}(\mathrm{~s}=\{1,2\})$ (source: self study)

The parameters $\mathrm{m}_{11}^{1}=1,9$ and $\mathrm{m}_{12}^{1}=-0,2$ are determined by coordinates of the points selected at the stage $\mathrm{D}$ in which the rules are placed. The parameters $\delta_{11}^{1}$, $\delta^{1}{ }_{12}, 1^{1}{ }_{11}, 1^{1}{ }_{12}$ are adjusted by means of fuzzy neural network whose form for three input variables and output variable $y_{i}$ is included in Figure 9 (value 1 is assumed for the output variable $\mathrm{y}_{1} \mathrm{i}$ ).

The adjustment takes place on the basis of error samples $\mathrm{E}_{0} \mathrm{u}$ visible in Table 14 and it is executed according to the error back propagation described at the stage $\mathrm{B}$ and gradient methods. After the execution of a series of experiments, the following values of adjusted parameters are assumed in the case under consideration: $\delta^{1}{ }_{11}=0,5138,1^{1}{ }_{11}=1,5496, \delta^{1}{ }_{12}=1,1077,1^{1}{ }_{12}=2,3234$ with an average absolute error on the training data $\mathrm{avE}_{0 \mathrm{M}} \mathrm{u}=0,1808$, and on the test data $\operatorname{avE}_{0 \mathrm{M}} \mathrm{t}=0,1361$.

\section{F The formation of model $M_{1}$ (sum of $M_{0}$ and $\mathrm{E}_{\mathbf{0 M}}$ )}

In case of sufficient precision - completion of modelling, otherwise - determination of error residuum $\mathrm{E}_{1}$ and continuation of modelling till a satisfying precision is achieved. The base model $\mathrm{M}_{0}$ is added to the error model $E_{0 M}$. Their sum forms a model $M_{1}$. The error model $E_{0 M}$ is subtracted from the error $E_{0}$ of base model and the residuum of error $E_{1}$ is achieved. The output of error model $\mathrm{E}_{0 \mathrm{M}}$ obtained at the stage $\mathrm{E}$ and the residuum of error $\mathrm{E}_{1}=\mathrm{E}_{0}-\mathrm{E}_{0 \mathrm{M}}$ for the training data considered in the example is presented Table 15. Average absolute error:

$$
\operatorname{avE}_{1} \mathrm{u}=\sum_{\mathrm{i}=1}^{9}\left|\mathrm{E}_{1} \mathrm{u}_{\mathrm{i}}\right| / 9=0,1796
$$

If an average absolute error of the residuum is not appropriately small, then a next fuzzy model of error residuum $\mathrm{E}_{1 \mathrm{M}}$ is formed and added to the previous models increasing its accumulated precision. In the case under consideration for the achieved model $\mathrm{M}_{1}$ an average absolute error on the training data is equal to 0,1796 , and on the test data is equal to 0,1482 . The output of the model $\mathrm{M}_{1}=\mathrm{M}_{0}+\mathrm{E}_{0 \mathrm{M}}$ and error of this model equal to the residuum of the error $\mathrm{E}_{1}$ is presented in Table 16.

Because a precision of the model $\mathrm{M}_{1}$ established in the example is considered as insufficient, the modelling of error residuum $E_{1}$ is continued according to the rules 
described at the stages D - F. It means that the model of error residuum $E_{1}$ is formed on the basis of the data listed in Table 17 together with placing the next rules in the points of extreme visible in Table: $(-2 ; 1,2434)$ and $(-1,1 ;-0,2067)$.
A described procedure (stages $\mathrm{D}-\mathrm{E}$ ) was repeated for times achieving an average absolute error on the training data 0,0127 , an on the test data 0,0696 . The parameters of retrieved fuzzy model established at the next stages are presented in Table 18.

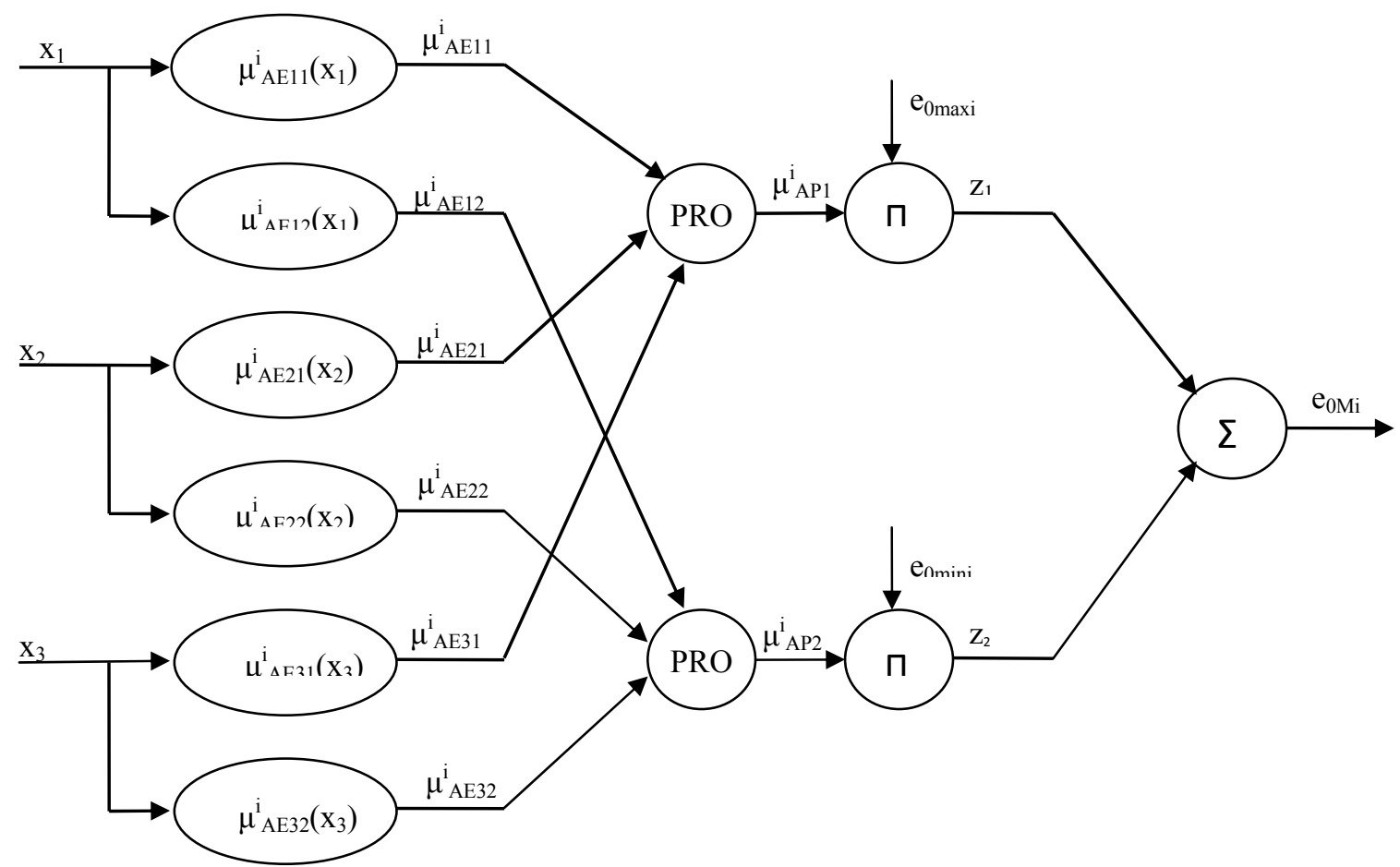

Figure 9. Fuzzy neural network for modelling the error $\mathrm{E}_{0}$ (source: self study)

Table 15. Model output $\mathrm{E}_{0 \mathrm{M}}$ and error residuum $\mathrm{E}_{1}$ (source: self study)

\begin{tabular}{|l|r|r|r|r|r|r|r|r|l|}
\hline $\mathrm{x}_{1} \mathrm{u}$ & $-2,0000$ & $-1,4000$ & $-1,1000$ & $-0,5000$ & $-0,2000$ & 0,1000 & 0,4000 & 1,6000 & 1,9000 \\
\hline $\mathrm{E}_{0} \mathrm{u}$ & 1,1978 & $-0,5296$ & $-1,1233$ & $-1,7707$ & $-1,8244$ & $-1,6981$ & $-1,3918$ & 1,6334 & 2,8397 \\
\hline $\mathrm{E}_{0 \mathrm{M}} \mathrm{u}$ & $-0,0456$ & $-0,4582$ & $-0,9166$ & $-1,7378$ & $-1,8208$ & $-1,7267$ & $-1,3715$ & 1,6321 & 2,8311 \\
\hline $\mathrm{E}_{1} \mathrm{u}$ & 1,2434 & $-0,0714$ & $-0,2067$ & $-0,0329$ & $-0,0036$ & 0,0286 & $-0,0203$ & 0,0013 & 0,0086 \\
\hline
\end{tabular}

Table 16. Output and error of the model $\mathrm{M}_{1}=\mathrm{M}_{0}+\mathrm{E}_{0 \mathrm{M}}$ (source: self study)

\begin{tabular}{|l|r|r|r|r|r|r|r|r|r|}
\hline $\mathrm{x}_{1} \mathrm{u}$ & $-2,0000$ & $-1,4000$ & $-1,1000$ & $-0,5000$ & $-0,2000$ & 0,1000 & 0,4000 & 1,6000 & 1,9000 \\
\hline $\mathrm{y}_{1} \mathrm{u}$ & 4,0000 & 1,9600 & 1,2100 & 0,2500 & 0,0400 & 0,0100 & 0,1600 & 2,5600 & 3,6100 \\
\hline $\mathrm{y}_{1 \mathrm{M} 0} \mathrm{u}$ & 2,8022 & 2,4896 & 2,3333 & 2,0207 & 1,8644 & 1,7081 & 1,5518 & 0,9266 & 0,7703 \\
\hline $\mathrm{E}_{0 \mathrm{M}} \mathrm{u}$ & $-0,0456$ & $-0,4582$ & $-0,9166$ & $-1,7378$ & $-1,8208$ & $-1,7267$ & $-1,3715$ & 1,6321 & 2,8311 \\
\hline $\mathrm{y}_{1 \mathrm{M} 1} \mathrm{u}$ & 2,7566 & 2,0314 & 1,4167 & 0,2829 & 0,0436 & $-0,0186$ & 0,1803 & 2,5587 & 3,6014 \\
\hline $\mathrm{E}_{1} \mathrm{u}$ & 1,2434 & $-0,0714$ & $-0,2067$ & $-0,0329$ & $-0,0036$ & 0,0286 & $-0,0203$ & 0,0013 & 0,0086 \\
\hline
\end{tabular}

Table 17. Output and error of the model $\mathrm{M}_{1}=\mathrm{M}_{0}+\mathrm{E}_{0 \mathrm{M}}$ (source: self study)

\begin{tabular}{|l|c|c|c|c|c|c|c|c|c|}
\hline $\mathrm{x}_{1} \mathrm{u}$ & -2 & $-1,4$ & $-1,1$ & $-0,5$ & $-0,2$ & 0,1 & 0,4 & 1,6 & 1,9 \\
\hline $\mathrm{E}_{1} \mathrm{u}$ & 1,2434 & $-0,0714$ & $-0,2067$ & $-0,0329$ & $-0,0036$ & 0,0286 & $-0,0203$ & 0,0013 & 0,0086 \\
\hline
\end{tabular}


Table 18. Parameters of established fuzzy model on the basis of the data from Table 12 (source: self study)

\begin{tabular}{|c|c|c|c|c|c|c|c|c|}
\hline & $\mathrm{a}_{11}$ & $\mathrm{a}_{12}$ & $\mathrm{yB}_{11}$ & $\mathrm{yB}_{21}$ & & & $\mathrm{avE}_{0} \mathrm{u}$ & $\mathrm{avE}_{0} \mathrm{t}$ \\
\hline $\mathrm{M}_{0}$ & $-2,0000$ & 1,9000 & 2,8022 & 0,7703 & & & 1,5567 & 0,7066 \\
\hline & $\mathrm{m}^{1}{ }_{11}$ & $\delta^{1}{ }_{11}$ & $1^{1}{ }_{11}$ & $\mathrm{~m}_{12}^{1}$ & $\delta^{1}{ }_{12}$ & $1^{1}{ }_{12}$ & & \\
\hline $\mathrm{E}_{0 \mathrm{M}}$ & 1,9000 & 0,4905 & 1,3058 & $-0,2000$ & 1,0501 & 2,4223 & 0,1796 & 0,1482 \\
\hline $\mathrm{E}_{1 \mathrm{M}}$ & $-2,0000$ & 0,2441 & 1,7382 & $-1,1000$ & 0,2389 & 0,6757 & 0,0130 & 0,0818 \\
\hline $\mathrm{E}_{2 \mathrm{M}}$ & 0,1000 & 0,5173 & 7,3531 & $-1,4000$ & 0,0890 & 0,0530 & 0,0120 & 0,0803 \\
\hline $\mathrm{E}_{3 \mathrm{M}}$ & $-2,0000$ & 0,6821 & 5,5034 & 0,4000 & 0,9634 & 7,7719 & 0,0127 & 0,0696 \\
\hline
\end{tabular}

\section{Stage 1.2 Fuzzy reasoning}

A fuzzy model formed according to the stage 1.1 constitutes an empirical knowledge base which is utilized for the forecasting based on a fuzzy reasoning. Having the data on a current (at the moment $t_{0}$ ) and planned (at the moments $t_{1}, \ldots t_{z}$ ) implementation state of functionalities SF of the DSS under consideration in a given enterprise and known values of selected indexes $\mathrm{W}$ of this enterprise before the implementation (at the moments $t_{-1}$ and $t_{0}$ ), a forecast of these indexes in subsequent periods $t_{1}, \ldots t_{z}$ is determined after the start of the implementation.

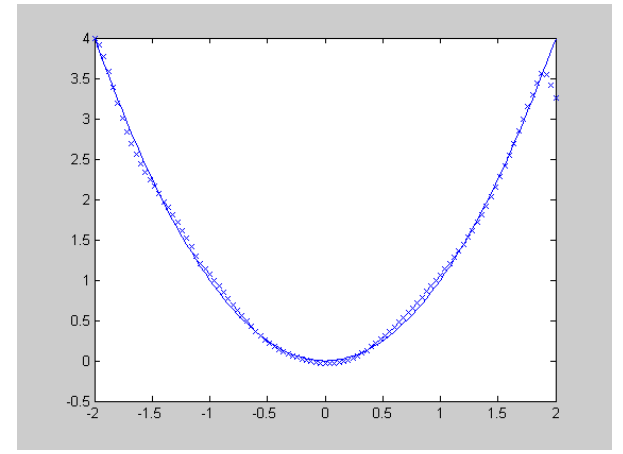

Figure 10. Results of fuzzy reasoning by means of fuzzy model with parameters from Table 18 for $\mathrm{x}_{1}=\{-2 ;-1,96 ; \ldots ; 1,92 ; 1,96 ; 2\}$. (source: self study)

A retrieval of forecast values boils down to the determination of values of output variables on the basis of the data of values of input variables by means of fuzzy model recorded in the form of fuzzy neural network with parameters established at the stage 1.1 . In case of exemplary fuzzy model, determined at the stage 1.1 whose parameters are listed in Table 18, the values of output variable $\mathrm{y}_{1}$ for the exemplary selected values of input variable $\mathrm{x}_{1}=\{-2 ;-1,96 ;-1,92 ; \ldots 1,92$; $1,96 ; 2\}$ were retrieved. The achieved results are presented in Figure 10 (for comparison: diagram of function $\mathrm{y}_{1}=\mathrm{x}_{1}^{2}$ is marked by a solid line).
An exemplary fuzzy value of input variable $\mathrm{x}_{1}=[0,4$ $0,50,50,7]$ and forecast fuzzy value of output variable $\mathrm{y}_{1}$, corresponding with it, achieved using a model with the parameters from Table 18 is presented in Figure 11.

\section{Stage 2}

Stage 2 concerns a forecast of DSS implementation realization time and cost and it is realized at two substages:

2.1 forecast of DSS implementation time taking into account a preparation state of the enterprise,

\section{2 forecast of DSS implementation cost.}

Stage 2.1 The forecast of DSS implementation time

The information on the time which is necessary to implement the DSS taking into account a current preparation state of enterprise $\mathrm{P}$ for the implementation is a result of this stage. A conduct procedure is presented on the basis of an example described below.

A model of implementation undertaking, presented in Figure 3 with a separation of preparatory actions listed in Table 2 - for the implementation CPG, and implementation and exploitation actions CWE for which estimated durations of actions CPG and durations of actions CWE determined imprecisely by means of trapezoidal fuzzy numbers are known, is given for a specified DSS. A preparation state - visible in Table 2 - for the implementation of specified enterprise in relation to individual preparatory actions of the undertaking at the moment $\mathrm{t}_{0}$ is given as well.

An estimated duration of already executed preparatory actions $\operatorname{cpg}_{1}, \operatorname{cpg}_{3}, \operatorname{cpg}_{4}$ is reduced to zero in the first step of proposed method on the basis of a report on the enterprise's preparation state for the implementation. 

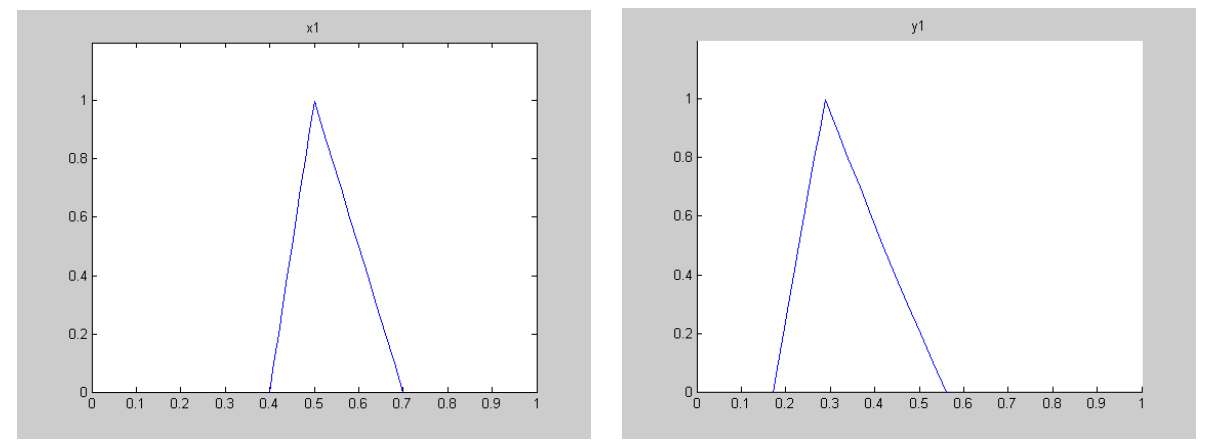

Figure 11. Results of fuzzy reasoning of output value $\mathrm{y}_{1}$ for fuzzy input value $\mathrm{x}_{1}$ (source: self study)

A horizontal representation of fuzzy numbers in the form of descending family of closed intervals is utilized in a further procedure. It means that fuzzy durations $\mathrm{T}_{\mathrm{i}}=\left[\mathrm{T}_{\mathrm{i} \_ \text {min }}, \mathrm{T}_{\mathrm{i} \_\mathrm{mL}}, \mathrm{T}_{\mathrm{i} \_\mathrm{mP}}, \mathrm{T}_{\mathrm{i} \_ \text {max }}\right]$ of individual actions are presented in the form of so called $\alpha$-sections $\mathrm{T}_{\mathrm{i}}^{\alpha}$ according to the formula:

$$
\begin{aligned}
& \mathrm{T}_{\mathrm{i}}^{\alpha}=\left[\mathrm{T}_{\mathrm{iL}}{ }^{\alpha}, \mathrm{T}_{\mathrm{iP}}{ }^{\alpha}\right]=\left[\alpha\left(\mathrm{T}_{\mathrm{i}_{-} \mathrm{mL}}-\mathrm{T}_{\mathrm{i}_{\_} \min }\right)+\right. \\
& \left.\mathrm{T}_{\mathrm{i}_{-} \min }, \mathrm{T}_{\mathrm{i}_{\text {_max }}}-\alpha\left(\mathrm{T}_{\mathrm{i}_{\_} \max }-\mathrm{T}_{\mathrm{i}_{\_} \mathrm{mP}}\right)\right]
\end{aligned}
$$

An exemplary form of horizontal representation of fuzzy durations of actions $\mathrm{cwe}_{2}, \mathrm{cwe}_{3}$, and $\mathrm{cpg}_{5}$ is shown in Table 19.

It can be noticed that for example for the section $\alpha=0$ the duration of action $\mathrm{cwe}_{2}$ is $[12 ; 16]$ days, action $\mathrm{cwe}_{3}$ $[14 ; 20]$ days, and action $\operatorname{cpg}_{5}[44 ; 60]$ days. Because the action $\mathrm{cpg}_{5}$ follows the action $\mathrm{cwe}_{3}$ then the duration of both these actions cannot last shorter than
$14+44=58$ days and it cannot last longer than $20+60$ $=80$ days, therefore it is $[58 ; 80]$ days. Comparing the duration of these two actions the duration of action $\mathrm{cwe}_{2}$, executed simultaneously with them, amounting to $[12 ; 16]$ days, it can be noticed that these actions cannot last shorter that maximum $\{58,12\}=58$ days and they cannot last longer than maximum $\{80,16\}=80$ days. The time needed to execute the mention actions in the form of trapezoidal fuzzy number equal to [58; $64 ; 68 ; 80]$ whose horizontal representation is shown in Table 20, is achieved as a result of continuation of such reasoning for every $\alpha$ - section.

The fuzzy duration of planned undertaking equal to $[124 ; 138 ; 165 ; 188]$ days, presented in Figure 12 is achieved performing a presented procedure for all actions of the analysed implementation.

Table 19. Division into $\alpha$-sections of fuzzy durations of actions $\mathrm{cwe}_{2}, \mathrm{cwe}_{3}$, and $\mathrm{cpg}_{5}$ (source: self study)

\begin{tabular}{|c|c|c|c|c|c|c|}
\hline \multirow{2}{*}{$\alpha$} & \multicolumn{2}{|c|}{$\mathrm{Tcwe}_{2}=[12,14,15,16]$} & \multicolumn{2}{c|}{$\mathrm{Tcwe}_{3}=[14,16,18,20]$} & \multicolumn{2}{c|}{$\mathrm{Tcpg}_{5}=[44,48,50,60]$} \\
\cline { 2 - 7 } & $\mathrm{Tcwe}_{2 \mathrm{~L}}$ & $\mathrm{Tcwe}_{2 \mathrm{P}}$ & $\mathrm{Tcwe}_{3 \mathrm{~L}}$ & $\mathrm{Tcwe}_{3 \mathrm{P}}$ & $\mathrm{Tcpg}_{5 \mathrm{~L}}$ & $\mathrm{Tcpg}_{5 \mathrm{P}}$ \\
\hline 1 & 14 & 15 & 16 & 18 & 48 & 50 \\
\hline 0,9 & 13,8 & 15,1 & 15,8 & 18,2 & 47,6 & 51 \\
\hline 0,8 & 13,6 & 15,2 & 15,6 & 18,4 & 47,2 & 52 \\
\hline 0,7 & 13,4 & 15,3 & 15,4 & 18,6 & 46,8 & 53 \\
\hline 0,6 & 13,2 & 15,4 & 15,2 & 18,8 & 46,4 & 54 \\
\hline 0,5 & 13 & 15,5 & 15 & 19 & 46 & 55 \\
\hline 0,4 & 12,8 & 15,6 & 14,8 & 19,2 & 45,6 & 56 \\
\hline 0,3 & 12,6 & 15,7 & 14,6 & 19,4 & 45,2 & 57 \\
\hline 0,2 & 12,4 & 15,8 & 14,4 & 19,6 & 44,8 & 58 \\
\hline 0,1 & 12,2 & 15,9 & 14,2 & 19,8 & 44,4 & 59 \\
\hline 0 & 12 & 16 & 14 & 20 & 44 & 60 \\
\hline
\end{tabular}


Table 20. Horizontal representation of fuzzy numbers $[58,64,68$ and 80$]$

(source: self study)

\begin{tabular}{|c|c|c|}
\hline$\alpha$ & \multicolumn{2}{|c|}{$[58,64,68,80]$} \\
\hline 1 & 64 & 68 \\
\hline 0,9 & 63,4 & 69,2 \\
\hline 0,8 & 62,8 & 70,4 \\
\hline 0,7 & 62,2 & 71,6 \\
\hline 0,6 & 61,6 & 72,8 \\
\hline 0,5 & 61 & 74 \\
\hline 0,4 & 60,4 & 75,2 \\
\hline 0,3 & 59,8 & 76,4 \\
\hline 0,2 & 59,2 & 77,6 \\
\hline 0,1 & 58,6 & 78,8 \\
\hline 0 & 58 & 80 \\
\hline
\end{tabular}

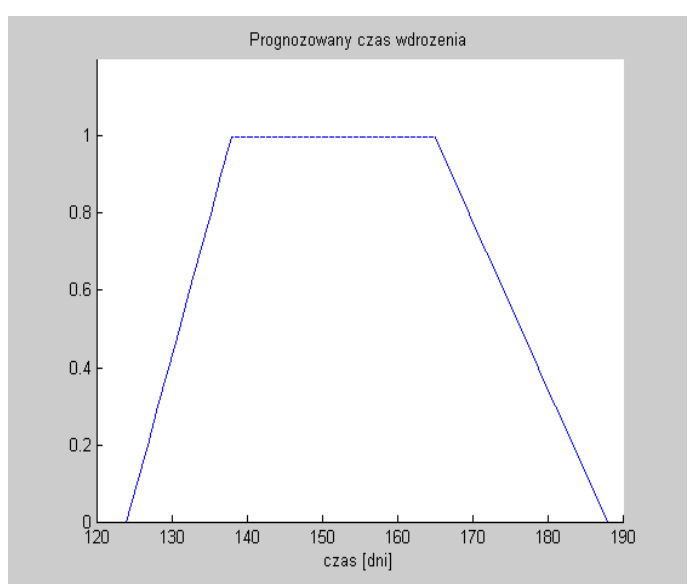

Figure 12. Fuzzy time of implementation (source: self study)

Stage 2.2 The forecast of DSS implementation cost

The determination of DSS implementation costs is a result of this stage. A way of procedure is discussed on the basis of an example presented below.

The costs of implementation undertaking of given DSS include the costs of purchase, implementation and maintenance. The purchase costs in the case under consideration include a licence costs and costs of server purchase. The implementation costs concern the costs of DSS service and they cover the costs of project management works including among other things a schedule preparation and acceptance of particular stages, costs of trainings, costs of works without participation of the customer and costs of implementation works at the seat of the customer. The maintenance costs include the system service costs which the customer bears since the contract conclusion and the costs of training of new employees. Therefore, the types of costs, connected with a planned implementation of the system under consideration, listed in Table 1 of this article, are given. The licence cost of specified system $\mathrm{KLC}=300$ of monetary units (corresponding with a determined number of users) is given and the rates of fixed costs (in the form of trapezoidal fuzzy numbers) expressed as $\%$ of licence costs, the reference rates, constituting a base of estimation of variable costs with the values of individual reference rates, and also the rates of unit variable costs expressed as \% of fixed costs (when there are no fixed costs as \% of licence costs) (Table 1) are determined for every type of cost.

In the first place, the values of fixed costs ( $\%$ of licence costs) and variables (product of unit variable cost value and reference rate value) are determined on the basis of the data for every type of cost RK, then their sum, to which the licence cost is added, is determined. The total cost of planned implementation, achieved in this way, is presented in Figure 13, and it amounts to $[385,8$; $403,56 ; 448,88 ; 468,3]$ of monetary units (m.u.).

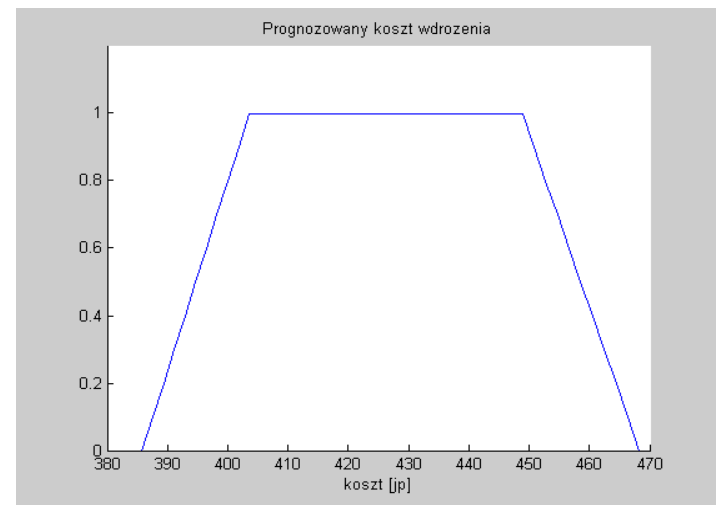

Figure13. Fuzzy cost of implementation (source: self study)

\section{Stage 3}

The multi-criteria assessment of DSS implementation effects - The determination of values of multi-criteria assessment of DSS implementation effectiveness in relation to target criteria preferred by the enterprise is a result of this stage.

The time determined at the earlier stages (corrected by a specified time of system exploitation) and the cost of planned undertaking and the forecast values of indexes of the enterprise from a planned implementation of DSS are subject to the assessment in relation to the required expectations of the enterprise. A partial assessment of every rate according to an appropriate target criterion is executed in the first step. A value of global assessment for all target criteria is determined in the second step. 
a)

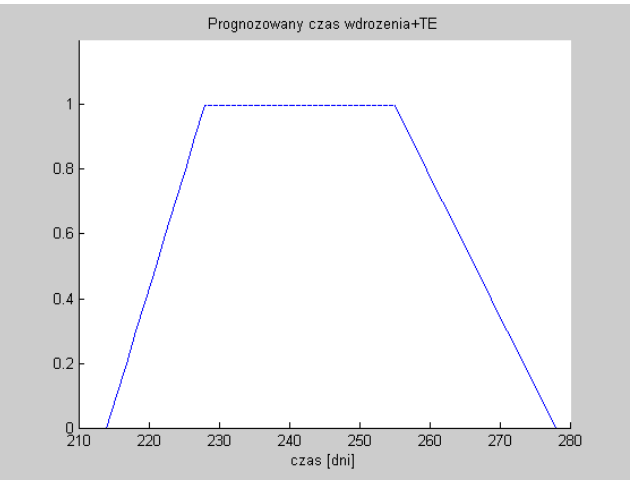

c)

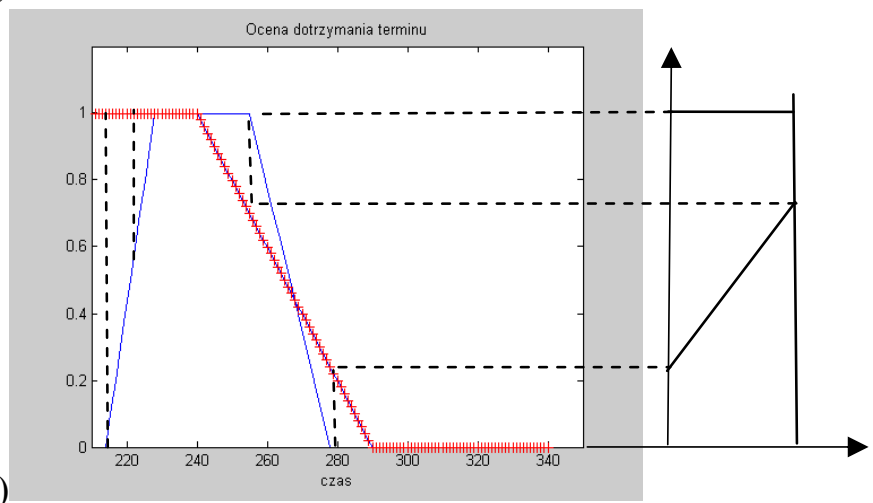

b)

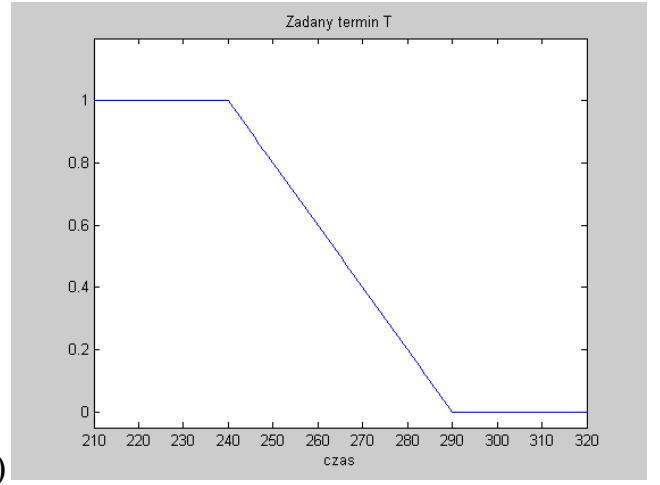

d)

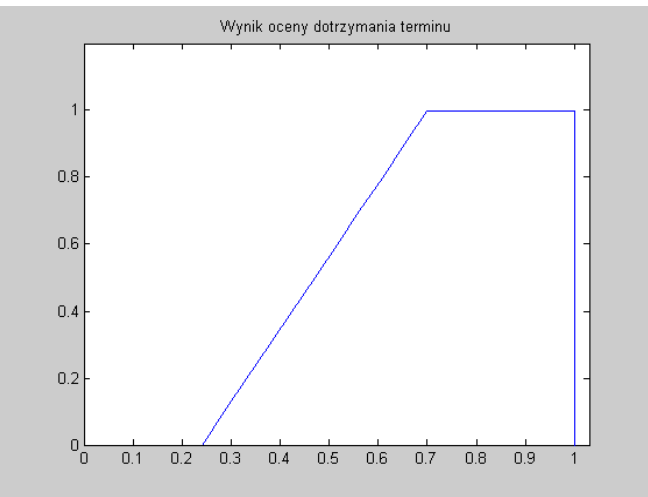

Figure 14. a) Undertaking time, b) Target criterion for undertaking time,

c) Assessment of time (a) in relation to criterion (b), d) Result of assessment from (c)

(source: self study)

Stage 3 - Step 1 The partial assessment according to an appropriate target criterion

The values of partial assessments for every target criterion are a result of this stage. A way of partial assessment determination on the basis of an example of selected target criterion which it is adherence of specified time limit is presented below.

The forecast implementation time, achieved at the stage 2.1, determined imprecisely in the form of trapezoidal fuzzy number, equal to [124, 138, 165, 188] days (Figure12) is given. The assumed system exploitation time equal to $\mathrm{TE}=90$ days is given as well. The time limit $\mathrm{T}$ of achievement of preferred values of indexes, specified by the enterprise, is determined imprecisely and it amounts to 240 days (maximum 290 days) (Figure 14b). An answer to a question whether a specified time limit shall be adhered to is retrieved.

Taking into consideration the assumed time of system exploitation $\mathrm{TE}=90$ days, the time needed for the implementation and achievement of preferred indexes is [214, 228, 255, 278] days (Figure 14a). The specified time limit $\mathrm{T}$ is 240 days (maximum 290 days) (Figure $14 \mathrm{~b})$. The assessment in relation to the specified time limit is presented in Figure 14c in which it is shown that the time needed for the implementation in the form of trapezoidal fuzzy number is assessed in relation to the affinity function for the specified time limit $\mathrm{T}$, assuming:

- the value equal to 1 when the implementation time is shorter or equal to 240 days,

- the value equal to 0 when the implementation time is equal or longer than 290 days,

- the values of linear function crossing the points $(240,1)$ and $(290,0)$, when the implementation time is longer than 240 days but shorter than 290 days.

Therefore the assessment which determines to what degree the adherence of specified time limit $\mathrm{T}$ is possible is executed for every $\alpha$-level. The assessment value achieved in this way is a fuzzy number shown in Figure $14 d$.

It can be noticed that with the most possible time of the whole undertaking which is equal to 228-255 days ( $\alpha=$ 1 ), the adherence of the time limit of 240 days with its certain infringement is possible. In case when the implementation lasts shorter than 240 days, then the time limit shall be adhered, i.e. a degree of time limit adherence is equal to 1 , and when the implementation lasts longer than 240 days but it does not exceed 255 days, 
then the time limit of 240 days shall not be adhered, however, it shall be acceptable because it shall be shorter than 290 days. The assessment value of 255 days in relation to the specified time limit $\mathrm{T}$ is equal to 0,7 . Therefore the most possible degree of adherence of time limit $\mathrm{T}$ on a scale of $[0,1]$ is $0,7-1$ in this case.

Because the longest possible time of undertaking, i.e. 278 days, exceeds the preferred time, i.e. 240 days but it does not exceed a possible time limit of 290 days maximally, the least possible degree of time limit adherence is equal to 0,24 .

The exemplary values of implementation time assessment in relation to the specified time limit in case of the afore-mentioned data for various $\alpha$-sections are listed in Table 21.

Table 21. Implementation time assessment in relation to specified time limit for exemplary $\alpha$-sections (source: self study)

\begin{tabular}{|c|c|c|c|c|}
\hline \multirow{3}{*}{$\frac{\alpha}{1}$} & \multicolumn{2}{|c|}{ Implementation time $\mathrm{t}$} & \multirow{2}{*}{\multicolumn{2}{|c|}{$\begin{array}{c}\text { Degree } \\
\text { of adherence } \\
\text { of time limit T }\end{array}$}} \\
\hline & \multirow{2}{*}{$\frac{\mathrm{t}_{\mathrm{L}}}{228}$} & \multirow{2}{*}{$\frac{t_{P}}{255}$} & & \\
\hline & & & 1 & 0,7 \\
\hline 0,9 & 226,6 & 257,3 & 1 & 0,654 \\
\hline 0,8 & 225,2 & 259,6 & 1 & 0,608 \\
\hline 0,7 & 223,8 & 261,9 & 1 & 0,562 \\
\hline 0,6 & 222,4 & 264,2 & 1 & 0,516 \\
\hline 0,5 & 221 & 266,5 & 1 & 0,47 \\
\hline 0,4 & 219,6 & 268,8 & 1 & 0,424 \\
\hline 0,3 & 218,2 & 271,1 & 1 & 0,378 \\
\hline 0,2 & 216,8 & 273,4 & 1 & 0,332 \\
\hline 0,1 & 215,4 & 275,7 & 1 & 0,286 \\
\hline 0 & 214 & 278 & 1 & 0,24 \\
\hline
\end{tabular}

Stage 3 - Step 2 The global assessment according to the specified target criteria

Having determined values of individual partial criteria $\mathrm{uWE}_{\mathrm{i}}$, achieved in the step 1, and their weights $\mathrm{QuWEi}_{\mathrm{u}}$ established according to the enterprise's preferences, an aggregation of partial assessments is executed, determining a value of target global assessment of planned undertaking. An additive and multiplicative criterion is utilized for the purposes of the aggregation (see [1], [2], [5] and [6]):

- additive criterion:

$$
\mathrm{DA}=\sum_{\mathrm{i}=1}^{\mathrm{k}} \mathrm{Q}_{\mathrm{uWEi}} \mathrm{uWE} \text {, }
$$

- multiplicative criterion:

$$
\mathrm{DM}=\prod_{\mathrm{i}=1}^{\mathrm{k}} \mathrm{uWE} \mathrm{E}_{\mathrm{i}}^{\mathrm{Q}_{\mathrm{uWi}}} \text {. }
$$

The use of two criteria during the aggregation of partial assessments gives a possibility of achievement of wider information on a gained final assessment. Because of the fact that the weights correspond with the preferences of given enterprise, they are identical with regard to both criteria.

For example, three fuzzy partial assessments are considered:

- time limit adherence (see Figure14d) $-\mathrm{uWE}_{1}$,

- budget adherence (see Figure15b) - $\mathrm{uWE}_{2}$ - assessment of forecast implementation cost [385,8; $403,56 ; 448,88 ; 468,3]$ in relation to the specified budget up to 440 (maximum 500) of monetary units shown in Figure 15a,

- achievement of preferred value of index $\mathrm{W}_{1}$ (see Figure 16b) whose forecast is determined according to the describe of the stage $1-\mathrm{uWE}_{3}$ - assessment of forecast value of index $\mathrm{W}_{1}$ in relation to the value below 0,1 (maximum 0,6 ) preferred by the enterprise (see Figure 16, Table 22).

The aggregation of these assessments according to the additive and multiplicative criterion using $\alpha$-sections whose results are presented in Table 23 and in Figure 17 is executed. Additionally, it is assumed that the criterion of assessment of index $\mathrm{W}_{1}$ (weight: $\mathrm{QuwE3}_{\mathrm{uw}}=$ $0,5)$, is the most preferred, and the criteria of time and cost assessment are preferred equally (weights: $\mathrm{Q}_{\mathrm{uWE} 1}=\mathrm{Q}_{\mathrm{uWE2}}=0,25$ ). The assessment is contained within a range of $[0,1]$.

From the achieved assessment it results that according to the additive criterion, the most possible degree of the realization of the targets assumed by the enterprise amounts to $0,70-0,81$; the least possible degree amounts to 0,23 and the highest possible degree amounts to 0,93 . However, according to multiplicative criterion, the most possible degree amounts to 0,69 0,79 , the least possible degree amounts to 0,16 and the highest possible degree amounts to 0,93 . Therefore there is a possibility that a planned undertaking allows the enterprise to achieve assumed targets event to the degree of 0,93 , however, their achievement only to the degree of 0,16 is possible as well. So as it can be seen, a preparation state of enterprise for the implementation and exploitation of specified DSS allows a given enterprise to achieve a preferred value of index $\mathrm{W}_{1}$ along with the adherence of acceptable time limit and budget. 
a)

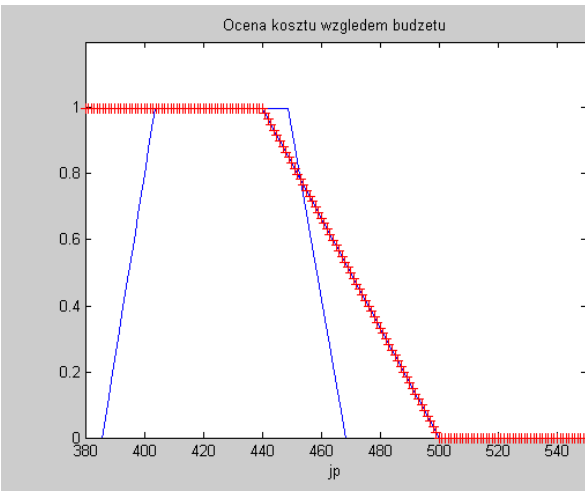

b)

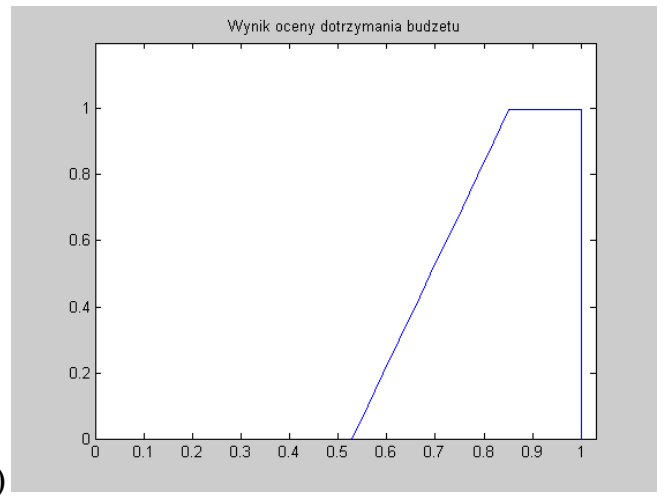

Figure 15. a) Assessment of cost in relation to limited budget, b) Result of assessment from (a) (source: self study)

a)

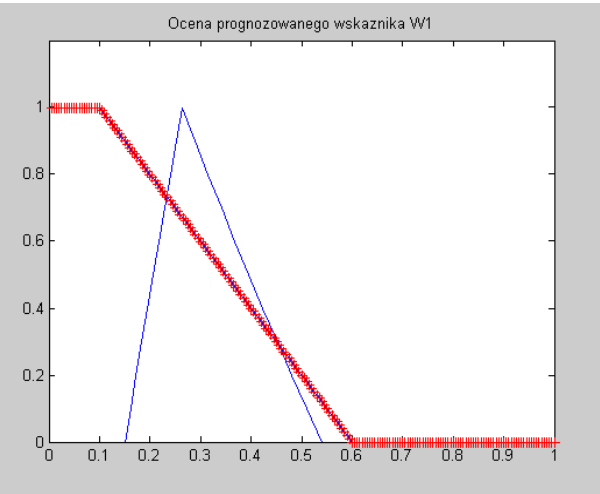

b)

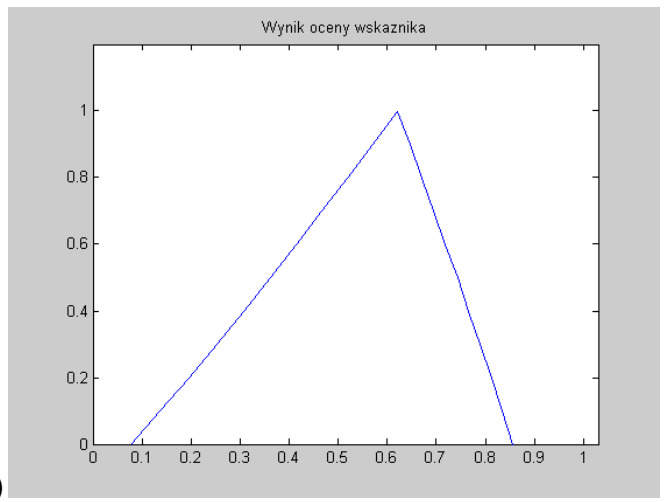

Figure 16. a) Assessment of forecast index $\mathrm{W}_{1}$ in relation to preferred value $\mathrm{WE}_{1}, \mathrm{~b}$ ) Result of assessment from (a) (source: self study)

Table 22. Assessment of forecast index $\mathrm{W}_{1}$ in relation to preferred value $\mathrm{WE}_{1}$ for exemplary $\alpha$-sections (source: self study)

\begin{tabular}{|c|c|c|c|c|}
\hline$\alpha$ & \multicolumn{2}{|c|}{ Forecast of index $\mathrm{W}_{1}$} & \multicolumn{2}{c|}{$\begin{array}{c}\text { Degree of achievement } \\
\text { of preferred value }\end{array}$} \\
\hline 1 & 0,2897 & 0,2897 & 0,6206 & 0,6206 \\
\hline 0,9 & 0,2772 & 0,315 & 0,6456 & 0,57 \\
\hline 0,8 & 0,2648 & 0,3406 & 0,6703 & 0,5188 \\
\hline 0,7 & 0,2526 & 0,3665 & 0,6948 & 0,4669 \\
\hline 0,6 & 0,2405 & 0,3927 & 0,719 & 0,4145 \\
\hline 0,5 & 0,2286 & 0,4193 & 0,7428 & 0,3614 \\
\hline 0,4 & 0,2168 & 0,4463 & 0,7664 & 0,3074 \\
\hline 0,3 & 0,2052 & 0,4739 & 0,7896 & 0,2521 \\
\hline 0,2 & 0,1938 & 0,5023 & 0,8124 & 0,1953 \\
\hline 0,1 & 0,1826 & 0,5316 & 0,8348 & 0,1367 \\
\hline 0 & 0,1716 & 0,5619 & 0,8567 & 0,0763 \\
\hline
\end{tabular}


Table 23. Global additive DA and multiplicative DM assessment using exemplary $\alpha$-sections (source: self study)

\begin{tabular}{|c|c|c|c|c|c|c|c|c|c|c|}
\hline$\alpha$ & \multicolumn{2}{|c|}{$\begin{array}{c}\text { Time limit } \\
\text { adherence }\end{array}$} & \multicolumn{2}{c|}{$\begin{array}{c}\text { Budget } \\
\text { adherence }\end{array}$} & \multicolumn{2}{c|}{$\begin{array}{c}\text { Achievement } \\
\text { of index }\end{array}$} & \multicolumn{2}{|c|}{ DA } & \multicolumn{2}{|c|}{ DM } \\
\hline 1 & 0,70 & 1 & 0,85 & 1 & 0,62 & 0,62 & 0,70 & 0,81 & 0,69 & 0,79 \\
\hline 0,9 & 0,65 & 1 & 0,82 & 1 & 0,57 & 0,65 & 0,65 & 0,82 & 0,65 & 0,80 \\
\hline 0,8 & 0,61 & 1 & 0,79 & 1 & 0,52 & 0,67 & 0,61 & 0,84 & 0,60 & 0,82 \\
\hline 0,7 & 0,56 & 1 & 0,75 & 1 & 0,47 & 0,69 & 0,56 & 0,85 & 0,55 & 0,83 \\
\hline 0,6 & 0,52 & 1 & 0,72 & 1 & 0,41 & 0,72 & 0,52 & 0,86 & 0,50 & 0,85 \\
\hline 0,5 & 0,47 & 1 & 0,69 & 1 & 0,36 & 0,74 & 0,47 & 0,87 & 0,45 & 0,86 \\
\hline 0,4 & 0,42 & 1 & 0,66 & 1 & 0,31 & 0,77 & 0,42 & 0,88 & 0,40 & 0,88 \\
\hline 0,3 & 0,38 & 1 & 0,63 & 1 & 0,25 & 0,79 & 0,38 & 0,89 & 0,35 & 0,89 \\
\hline 0,2 & 0,33 & 1 & 0,59 & 1 & 0,20 & 0,81 & 0,33 & 0,91 & 0,29 & 0,90 \\
\hline 0,1 & 0,29 & 1 & 0,56 & 1 & 0,14 & 0,83 & 0,28 & 0,92 & 0,23 & 0,91 \\
\hline 0 & 0,24 & 1 & 0,53 & 1 & 0,08 & 0,86 & 0,23 & 0,93 & 0,16 & 0,93 \\
\hline
\end{tabular}
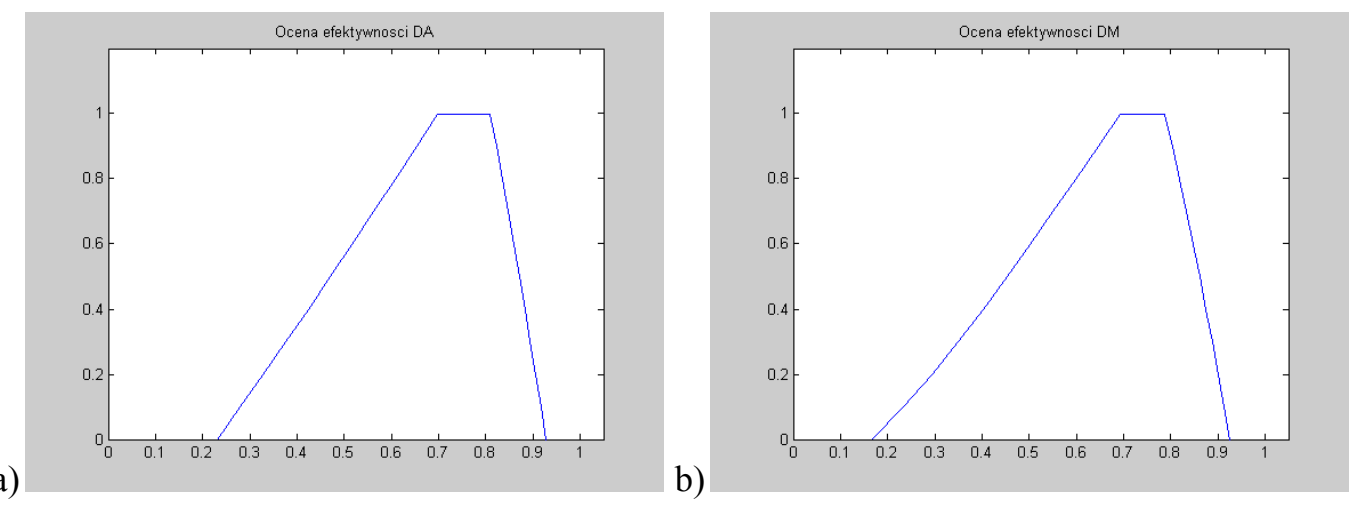

Figure 17. a) Result of global additive assessment b) Result of global multiplicative assessment (source: self study)

\section{The computer-aided support of multi-criteria assessment of DSS implementation effectiveness}

The computer-aided support of multi-criteria assessment of DSS implementation effectiveness, in which appropriate modules - with which buttons shown in Figure 18 correspond - are assigned to individual stages of the method, is an implementation of multi-criteria assessment method of DSS implementation effectiveness. The system allows to execute an effectiveness assessment of planned implementation of specified DSS in a selected enterprise in relation to its requirements. It is assumed that these requirements are determined by means of values of indexes, preferred by the enterprise, describing the effects of given implementation which it would like to achieve in a specified time limit and without going over a limited budget.

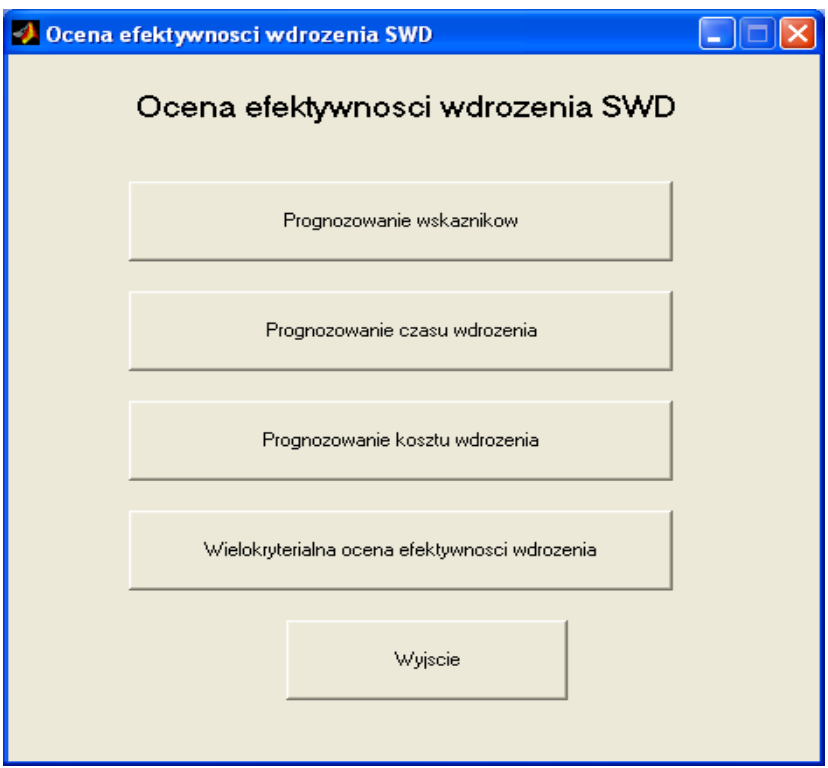

Figure 18. Main window of assessment system of DSS implementation effectiveness (source: self study) 
The system is built of two layers. The first layer is constituted by a computable part, being a computer-aided implementation of the method describing in the point 3 of the article, however, the second layer is formed by a graphic interface supporting the user in the introduction of the data, realization of individual stages of proposed method and graphic interpretation of achieved results. The system is implemented in the MATLAB environment.

The operation of the system boils down to the determination of:

- forecast values of selected indexes of the enterprise from a planned implementation, using a knowledge base which is created on the basis of earlier gained experiences, by means of module: Prognozowanie wskaźników (eng. Forecast of indexes),

- duration of planned implementation undertaking, taking into consideration the enterprise' preparation state, by means of module: Prognozowanie czasu wdrożenia (eng. Forecast of implementation time),

- costs of planned undertaking, by means of module: Prognozowanie kosztu wdrożenia (eng. Forecast of implementation cost),

- multi-criteria assessment of target effectiveness of planned undertaking in relation to subjective criteria preferred by the enterprise (preferred time, cost and values of indexes), by means of module: Wielokryterialna ocean efektywnego wdrożenia (eng. Multi-criteria assessment of implementation effectiveness).

\section{$5 \quad$ Summary}

The presented multi-criteria assessment method of DSS implementation effectiveness enables to forecast the effects of planned DSS implementation and their assessment in relation to the implementation objectives, preferred by a given enterprise. For these purposes it makes use of the knowledge collected on the basis of earlier realized implementations and imprecise description of parameters in order to take the uncertainty connected with the future into consideration. A system serving to support a DSS implementation process in the enterprises is a computer-aided implementation of the method.
6

\section{References}

[1] Dymowa L., Figat P., Zenkowa A. - Metoda $i$ oprogramowanie do oceny wielokryterialnej $i$ wielopoziomowej decyzji $w$ warunkach niepewności rozmytej [at] III Krajowa Konferencja nt. Metody i systemy komputerowe w badaniach naukowych i projektowaniu inżynierskim. Kraków, 1921 November 2001, pp. 575-576.

[2] Figat P. - Opracowanie metody $i$ oprogramowania do wielokryterialnej $i$ wielopoziomowej oceny alternatyw w zagadnieniach podejmowania decyzji. Praca magisterska, Politechnika Częstochowska, Częstochowa 2002.

[3] Piegat A. - Modelowanie i sterowanie rozmyte. Akademicka Oficyna EXIT, Warszawa 1999.

[4] Piegat A. - Fuzzy Modelling and Control. SpringerVerlag, Berlin/Heidelberg 2001.

[5] Róg P. - Opracowanie metodyki i oprogramowania do operowania na danych przedziałowych i fuzzy $w$ zastosowaniach modelowania procesów produkcyjnych i podejmowania decyzji. Praca magisterska, Politechnika Częstochowska, Częstochowa 2002,

[6] Róg P. - The method of Intervals Ordering Based on the Probibalistic Approach [in] Computer Science, Vol 1, No. 1, 2000, pp. 103-108.

[7] Ważna L. - Application of fuzzy modelling and inference to building the tool of support of the effects evaluation of ERP APS system implementation in enterprise [in] Management, Vol. 12, No. 1, 2008, pp. 202-212.

[8] Ważna L. - Ocena wdrożenia zintegrowanego rozwiqzania informatycznego wspomagajacego zarzq̨dzanie wiedza $w$ średnim przedsiębiorstwie produkcyjnym [in] Zeszyty Naukowe Uniwersytetu Szczecińskiego. Ekonomiczne Problemy Usług, No. 544 (No. 35), 2009.

[9] Ważna L. - Wykorzystanie modelowania rozmytego do oceny efektywności celowej planowanego wdrożenia ERP APS [in] Modele inżynierii teleinformatyki: wybrane zastosowania (ed. M. Kopczewski). Wyd. Ucz. Politechniki Koszalińskiej, Vol. 3, Koszalin 2008, pp. 282-287. 